\title{
The Early Permian fossil record of Gondwana and its relationship to deglaciation: a review
}

\author{
M. H. Stephenson*
}

British Geological Survey, Keyworth, Nottingham, NG12 5GG, United Kingdom. mhste@bgs.ac.uk

L. Angiolini

Dipartimento di Scienze della Terra “A. Desio”, Università degli Studi di Milano, Via Mangiagalli 34, Milano, 20133, Italy

M. J. Leng

NERC Isotope Geosciences Laboratory, Keyworth, Nottingham, NG12 5GG, United Kingdom

*Corresponding author

Number of words 12918 (including refs and figure captions)

Number of references 150

Number of tables 0

Number of figures 5

Running header: Early Permian deglaciation 


\section{Abstract}

Deglaciation sequences of Early Permian age in Gondwana have until now been distinguished mainly on lithological criteria by reference to climate-sensitive lithologies and associated geochemistry; whereas identification on biotic criteria such as vegetational or faunal change has not been employed. Present palaeontological data, which are widely-scattered geographically, and of different stratigraphic scales and resolutions show diversity increase from glacial conditions to post glacial conditions. Amongst the marine fauna, a cold water fauna consisting of bivalves such as Eurydesma and Deltopecten, and brachiopods such as Lyonia and Trigonotreta, were established in the earliest post glacial marine transgressions. Above this is a more diverse, increasingly warmer, temperate fauna, including brachiopods, bryozoans, bivalves, cephalopods, gastropods, conularids, fusulinids, small foraminifers, asterozoans, blastoids and crinoids. The palynomorph succession shows change from monosaccate pollen assemblages, associated with fern spores, to more diverse assemblages with common non-taeniate bisaccate pollen. In Oman, where this has been studied in greatest detail, the upland saw changes from a glacial monosaccate pollen-producing flora to a warmer climate bisaccate pollen-producing flora; while in the terrestrial lowlands, a parallel change occurred from a glacial fern flora to a warmer climate colpate pollen-producing and lycopsid lowland flora. The sedimentary organic matter of the associated clastic rocks shows a decreasing $\delta^{13} \mathrm{C}$ trend believed to reflect palaeoatmospheric change due to postglacial global warming.

Early Permian farfield isotope studies, compiled by other workers, from brachiopods from the southern Urals, show a $\delta^{18} \mathrm{O}$ decline of $2.5 \%$ in the Early Permian (Asselian 
to Artinskian) and stable $\delta^{13} \mathrm{C}$ values of around $+4.3 \%$ in the same period. This farfield evidence is in part consistent with palaeontological data since the most likely cause for the decline in $\delta^{18} \mathrm{O}$ is the return of isotopically light waters to the oceans from melting of glaciers at high latitudes.

At present we are living in an interglacial stage of the Late Cenozoic ice age that began around the earliest Oligocene (Crowell 1995) and has not yet ended. However the Carboniferous-Permian ice age is the most widespread and geologically wellrepresented ice age of the Phanerozoic and has the benefit that it ended more than 270 million years ago, and therefore can be studied in its entirety. By studying the waning glaciation of the Early Permian we may be able to learn more of the interplay of factors influencing glaciation, and hence learn more of the effects that might be 
expected in the near future in our own era.

The Late Palaeozoic glaciation of Gondwana comprised three distinct nonoverlapping episodes. Though there is some controversy about their precise timing (see for example Veevers \& Powell 1987, Isbell et al. 2003, Jones \& Fielding 2004), it appears that two short glaciations occurred in the Frasnian (latest Devonian) and Mid Carboniferous respectively, and that the glacigene rocks associated with them were deposited mainly by alpine glaciers. The third and latest glaciation of Pennsylvanian to Early Permian age is thought to have been more widespread as there is evidence for continental ice sheets covering a total area of 17.9 to $22.6 \times 10^{6} \mathrm{~km}^{2}$ (Isbell et al. 2003, López-Gamundí 1997, Veevers et al. 1994, Veevers \& Tewari 1995, Wopfner \& Casshyap 1997). The sedimentary rocks deposited in this last major glacial episode occur in cratonic basins (e.g. Kalahari, Rubh al Khali and Paraná basins; Veevers et al. 1994, Levell et al. 1988); rift basins (e.g. Damodar, Son, Mahanadi basins; Veevers \& Tewari 1995); foreland basins (e.g. Sydney and Karoo basins; Jones \& Fielding 2004, Stollhofen et al. 2000, Veevers et al. 1994); and successor basins (central Transantarctic Mountains; Isbell 1999) that are now exposed in South America, the Falkland Islands, Africa, Arabia, Madagascar, Antarctica, India and Australia (Fig. 1).

Two main facies have been recognized (Isbell et al. 2003). The first consists of massive diamictite resting on striated surfaces, sheared diamictite and sandstone and shale. These rocks were deposited subglacially as lodgement and deformation till, and in glaciofluvial and glaciolacustrine palaeoenvironments. The second facies association consists of massive diamictite overlying gradational and sharp contacts, stratified diamictite, dropstone-bearing shales and shales without dropstones. These 
rocks represent diverse styles of glaciomarine deposition including deposition at or near an ice front, rain out debris from ice shelves or ice tongues, deposition from rafts of ice, and open marine sedimentation.

Within Lower Permian strata, an abrupt change from glacial to post glacial deposits records the rapid withdrawal of ice from depositional basins throughout Gondwana (Isbell et al. 2003). In most basins a distinct contact between glacial facies below and fluvial, lacustrine and marine clastic facies above occurs. The marine facies may be associated with the Eurydesma fauna (Dickins 1984) or with other cold to temperate water faunas such as that of the Manendragarh Limestone in India (Chandra 1994, Frakes et al. 1975, Shah \& Sastry 1975, Venkatachala \& Tiwari 1987), the Callytharra Formation in Western Australia (Dickins 1992) and the Saiwan Formation/Haushi limestone in Oman (Angiolini et al. 2003). Waning of Early Permian glaciation in the Gondwana continent was also manifested in farfield events of Euramerica and Tethys in terms of lithology and plant evolution (Ziegler et al. 2002), macropalaeontology (Angiolini et al. 2005), cyclic sedimentation related to eustatic change (Isbell et al. 2003), oxygen and hydrogen isotope ratios in pedogenic phyllosilicates (Tabor \& Montañez 2005) and seawater isotope composition (Veizer et al. 1999, Korte et al. 2005).

The biostratigraphy of Gondwanan Early Permian post-glacial sections is relatively well known in isolation, but the detailed evolution of biota after the glaciation in the context purely of palaeoclimate rather than in terms of biostratigraphy, is not well studied. The advantages of developing an Early Permian biotic deglaciation model would be in understanding in detail the response of life to increasing temperatures and other climate change. Potentially, measures of extinction rate versus time and versus 
rate of palaeoenvironmental change (perhaps quantified in terms of per mille $\delta^{13} \mathrm{C}$ change) could be developed if an Early Permian biotic deglaciation model could be scaled against time. Such measures would be very useful in the study of modern biotic change during global warming. In addition, understanding some of the palaeoclimatic controls on deglaciation may be important in geological environments that are well known for accumulation of coal, gas and oil (see Potter et al. 1995), and in understanding the distribution of so-called post glacial 'hot shales' which can be important source rocks of hydrocarbons.

The purpose of this chapter is to summarise and synthesise palaeontological and isotopic data relating to post glacial Early Permian climate change and to discuss the progress and challenges associated with developing an Early Permian biotic deglaciation model

\section{Timing of Early Permian deglaciation}

Biostratigraphic correlation of facies of most Early Permian deglaciation within the northern Gondwanan basins and in the Karoo, Falkland Island and Antarctic basins indicate that deglaciation took place in the late Asselian or early Sakmarian (Crowell 1995, Eyles et al. 2002, Isbell et al. 2003, Stephenson \& Osterloff 2002, Stephenson et al. 2005, Tiwari 1994, Veevers \& Powell 1987, Vijaya 1994, Wopfner \& Kreuser 1986, Wopfner 1999) in or around the Granulatisporites confluens palynomorph biozone of Foster \& Waterhouse (1988). In basins at lower latitudes during the Permian (see Isbell et al. 2003), for example the Solimões, Amazonas and Parnaíba basins in present day northern South America, and along the Panthalassan margin of South America (e.g. the Tepuel, Calingasta, Uspallata and Paganzo basins), glaciation 
was restricted to the Mississippian and Pennsylvanian (González Bonorino 1992, López-Gamundí et al. 1992, Isbell et al. 2003). In eastern Australia and Tasmania there is evidence of post-Sakmarian glaciation in the form of lonestones, and the eastern Australian post-Sakmarian succession as a whole has been regarded as being indicative of a cool climate (Dickins 1978, 1996; Martini \& Glooschenko 1985, Martini \& Banks 1989). Lonestones have been reported to occur at three levels in the Bowen Basin (Dickins 1996), and in the Sydney Basin (Dickins 1996, Eyles et al. 1998) and Tasmania (Banks \& Clark 1987). Dickins (1996) discussed lonestone occurrences and noted their coincidence with glendonites, concluding that there is evidence for post-Sakmarian glaciation in the area. Crowell (1995) considered the lonestones in the Sydney Basin to be large enough to suggest nearby glaciation, whereas those in the Bowen Basin to be of rafted iceberg origin and therefore not necessarily suggestive of nearby glaciation. Recent work (Jones \& Fielding 2004) also casts doubt on post Sakmarian glaciation in the Bowen and Galilee basins, and in the New England fold belt of Queensland. Noting the persistence of glaciation, at least in the extreme SE of Australia and in Tasmania, and distribution of deglaciation sediments in other areas of Gondwana, Crowell (1995) concluded that glaciation persisted longer on the polar side of the Gondwana margin than along the Tethyan margin, and Frank et al. (2005) suggested persistent glacial conditions may have been maintained by up welling of cold water during sea level highstands.

Aside from southeast Australia and the northerly basins of South America, the weight of sedimentological and geochemical evidence therefore indicates that most Gondwanan deglaciation took place in the late Asselian or early Sakmarian (Crowell 1995, Isbell et al. 2003, Wopfner 1999). However the evidence for deglaciation is 
mainly sedimentological, and biotic change has not, as a rule, been considered. Thus the relationship between sedimentologically-defined deglaciation and biotic change during post glacial warming needs to be examined.

\section{Sedimentologically-defined deglaciation}

Most Carboniferous-Permian deglaciation sequences are identified on sedimentological and associated geochemical data (e.g. Apak \& Backhouse 1999, Charrier 1986, Crowell 1995, Dickins 1996, Diekmann \& Wopfner 1996, Eyles \& de Broekert 2001, Eyles et al. 1997, Faure \& Cole 1999, Gonzalez 1997, González Bonorino 1992, Isbell \& Cúneo 1996, López-Gamundí et al. 1992, Santos et al. 1996, Scheffler et al. 2003, Stollhofen et al. 2000, Theron \& Blignault 1975, Visser \& Young 1990, Visser 1995, 1996, 1997, Wopfner \& Diekmann 1996, Wopfner 1999). Some studies (e.g. Kneller et al. 2004) revealed local detail of glacial melting, changing sediment supply and incidences of local scale catastrophic sedimentation events. However, a distinction should be made between deglaciation in the sense of glacial melting related to climate warming and attendant biotic response, and sedimentological concepts of deglaciation, which primarily describe the sedimentological (usually fairly local) effects of the demise of glaciers. Visser (1997) defined a deglaciation sequence as '.. an upward thinning sediment body (or package) deposited seaward of the ice-grounding line during a major recessional phase of a marine ice margin..'. Other authors (e.g. Wopfner 1999) have used much broader definitions not confined to sedimentological criteria or to the marine realm, but encompassing mineralogical and geochemical aspects as well as considering aspects of climate. It seems unlikely that all deglaciation sequences identified purely 
on sedimentological grounds, for example employing Visser's definition, would have a biotic response. Studies of deglaciation by Visser $(1996,1997)$ showed that in close similarity to Holocene marine ice sheets, the ice sheets of the Karoo and Kalahari basins of southern Africa were unstable during sea level fluctuations. During sea level rise the ice sheet margin loses its points of contact with the ground and therefore the ice sheet retreats to a stable upglacial position. Thus, Visser (1997) showed that in the Karoo, the primary reason for glacial melting in some parts of the succession is not warming but sea level change. This has also been established for modern deglaciation, for example in the Irish Sea (Eyles \& McCabe 1989). Visser's observations of sea level change and deglaciation were primarily concerned with explaining sedimentary cycles of varying glacial influence, but these cycles, because they were controlled by sea level, are not the same as climatic 'glacials' and 'interglacials' nor are they likely to relate to coherent parallel changes in biota. Thus care is needed when identifying deglaciation sequences that might be studied for biotic change.

Eyles et al. (2002) demonstrated a similar independence of sequences interpreted to be of deglacial origin from simple climate warming. They commented that models like those developed by Visser that link deglaciation to sea level change, and which assume therefore that events or key lithologies have sequence-stratigraphic global correlation significance, may be flawed because of local tectonic controls. Eyles et al. (2002) applied a new Early Permian palynological biozonation across seven western Australian basins (Bonaparte, Canning, Carnarvon, Collie, Gunbarrel and Perth basins), and concluded that shales previously considered to be of a common deglacial eustatic origin were of different ages. They concluded that some post-glacial shales were present due to local tectonic subsidence rather than deglacial eustatic sea level 
rise.

Thus the key point in identifying successions for study of biotic response to deglaciation is to be able to distinguish between sequences interpreted to be deglacial in origin, caused primarily by local tectonics, sea level rise or climate change. Clearly these are linked causally but for an understanding of biotic change in relation to deglaciation only those sequences identified as being related to climate change are worthy of detailed further study.

\section{Previous studies of biotic change associated with}

\section{Asselian-Sakmarian Gondwana deglaciation}

Gondwana glacial deposits are well known for the almost complete lack of macrofauna between the Namurian-Westphalian and late Asselian (Truswell 1980, Jones \& Truswell 1992, Kemp et al. 1977), however palynomorphs in the form of spores and pollen, and other non-terrestrial propagules are quite common in the same deposits. The post glacial (post-mid Asselian) macrofauna and macroflora is also more diverse, reflecting climatic amelioration, and includes brachiopods, bivalves, gastropods, conularids, bryozoans, echinoderms, barnacles, foraminifera, ostracods, fishes, asterozoans, nautiloids, ammonoids, insects and plants (see for example; Angiolini et al. 1997, 2003, 2004, 2006; Archangelsky 1990, Archbold \& Dickins 1996, Archbold 1999, 2000; Briggs 1998, Chandra 1994, Closs 1970, Cousminer 1965, Dickins 1957, Foster \& Waterhouse 1988, Foster \& Archbold 2001, Frakes et al. 1975, Gonzalez 1997, Hudson \& Sudbury 1959, Larghi 2005, Leonova, 1998, Pant 1996, Shah \& Sastry 1975, Venkatachala \& Tiwari 1987, Vijaya 1994, Waterhouse 1997). Similarly, palynomorphs indicate a general increase in diversity in postglacial 
Early Permian sediments (Bharadwaj 1969, Truswell, 1980, Stephenson et al. 2003). However most studies of both palynology, fauna and flora have been concerned with taxonomy or biostratigraphy, rather than been aimed at detailed study of climate change.

Because of their abundance throughout, palynomorphs are the dominant method of biostratigraphic correlation in Gondwanan Lower Permian studies. There are too many studies to be listed here, but a number of publications summarise data for the different regions of Gondwana and form the basis for initial attempts at panGondwanan correlation. These include for South America: Russo et al. (1980) and Vergel (1993) for the Chacoparana Basin in Argentina; Césari \& Gutiérrez 2000 and Azcuy \& Jelin (1980) for the Paganzo Basin, Argentina; Marques-Toigo (1991) and Souza (2003) for the Paraná Basin of Brasil. Archangelsky et al. (1980) and Azcuy (1979) also summarised data for the whole of South America. Attempts at pan African or pan southern African palynological correlation schemes include those of Falcon et al. (1984), Anderson (1977), Falcon (1975), MacRae (1988), Hart (1967) and Millsteed (1999). In Arabia, palynological schemes were summarised and presented as a unified preliminary scheme by Stephenson et al. (2003). In India summaries of schemes include those of Vijaya et al. (2001), Tiwari (1994) and Venkatachala et al. (1995). Early Permian Australian palynostratigraphy was summarised by Price (1983, 1997), Kemp et al. (1977) and Foster (1983) but detailed basinal studies have also been published (e.g. Galilee Basin, Jones \& Truswell (1992); Collie Basin, Backhouse (1991); Canning Basin, Powis (1979, 1984); Foster \& Waterhouse (1988). In Antarctica some palynostratigraphy is available for the Asselian-Sakmarian (e.g. Lindström 1995, Kyle 1977, Farabee et al. 1991). A few authors have attempted to 
summarise and correlate across the Gondwana region as a whole using palynology (e.g. Bharadwaj 1969, Truswell 1980, Kemp 1975).

Considering the undoubted wealth of palaeontological, and particularly palynological data, from glacial and deglacial Lower Permian rocks it is surprising that most studies of biotic change in relation to deglaciation have been rather general in character and have not attempted detailed bed by bed or meter by meter reconstruction of biotic change. Most have been concerned with generalities reconstructing climate change over long stratigraphic intervals with rather low sampling densities and using data from a wide geographical area (e.g. Dickins 1985, 1992, 1996).

\section{South America}

There have been a number of general studies examining faunal and floral changes through the Upper Palaeozoic in South America. González (1997, p. 235; and references therein) working on the basins of Argentina concluded that '...the origins and extinctions of the major Carboniferous and Early Permian faunal groups are closely associated with sedimentological evidence of climatic alterations due to temperature ranges...'. González (1997) recognised two major faunal groups in the Early Permian of Argentina, the Uspallatian and the Bonetian. The first, characterised by Cancrinella cf. farleyensis (Etheridge \& Dun), was considered by González (1997) to be of Asselian age and to represent glacial conditions, while the second (considered of Sakmarian age) was associated with cold-water transgression and characterised by Eurydesma, Merismopteria, Megadesmus and Deltopecten. Gonzalez (1997) considered that the demise of the Bonetian fauna corresponded with the last Permian glaciation in Argentine basins. 
However, the faunal changes described by Gonzalez (1997) are based on erroneous age attribution (Simanauskas \& Cisterna 2001) since his Uspallatian glacial fauna has been shown to be younger (Sakmarian) by Cisterna \& Simanauskas (2000). Also, the Tivertonia jachalensis-Streptorhynchus inaequiornatus Biozone of the Tupe Formation of the Paganzo Basin, considered to be Late Carboniferous by Gonzalez (1997), is given a middle-late Asselian age by Archbold et al. (2004).

Cisterna \& Simanauskas (2000), Simanauskas \& Cisterna (2001), Cisterna et al. (2002a, b) and Archbold et al. (2004) have recently established a revised biostratigraphy and correlation of Upper Carboniferous-Lower Permian brachiopods of the Precordilleran basins of Argentina (Rio Blanco, Calingasta-Uspallata, Paganzo, Tepuel-Genoa basins). Simanauskas \& Cisterna (2001) described an uppermost Carboniferous-Lower Permian macrofaunal assemblage from the El Paso Formation of the Calingasta-Uspallata Basin. This fauna, previously considered to be Early Carboniferous in age, is recorded in shales between diamictites and shows a gradual increase in biodiversity.

The most complete faunal succession has been described from the Rio Blanco Basin (lower and middle members of the Rio del Penon Formation) as consisting of three brachiopod associations spanning the Asselian-early Sakmarian (Cisterna \& Simanauskas 2000). The lower association (Assemblage I) comes from black shales above sandstones, conglomerates and paraconglomerates (diamictites?). The authors do not interpret the faunal succession in terms of biotic change after the Gondwanan glaciation, but they indicate its affinity to the Asselian-Tastubian faunas of Peninsular India and of the Lyons Group and Callytharra Formation of Western Australia.

Trigonotreta sp. from their Assemblage I is similar to the primitive species of the 
Trigonotreta group such as Trigonotreta hesdoensis (Sahni and Dutt) from the Asselian-early Tastubian of Peninsular India. This fauna is regarded as early Asselian by Archbold et al. (2004). Interestingly Associations II and III do not show a significant increase in biodiversity with respect to the lower assemblage, even if some of their characterizing species are similar to species of the Sakmarian of Western Australia (species of Costatumulus, Neochonetes and Tivertonia). According to Archbold et al. (2004), assemblages II and III span the middle Asselian-early Sakmarian time interval.

A general study of South American floral change in relation to climate change is that of Goldberg (2004), who studied macro and microfloral diversity throughout the Permian in the Paraná Basin in southern Brasil and compared this with results from nine Australian Gondwanan basins. Her methodology was to count the number of taxa (genera/species) and graph these against lithostratigraphic and chronostratigraphic units as well as climate sensitive lithologies. Data points corresponded nominally to the centre of formations so essentially this is a broad based study too coarse to allow detailed study of postglacial climate change. The study, however, showed a great increase in microfloral diversity from the Asselian-early Sakmarian Itararé Group (dominantly glacial) to the postglacial coal bearing late Sakmarian-early Kungurian Rio Bonito Formation, probably related to climatic amelioration. An accompanying decrease in floral diversity was attributed by Goldberg (2004) to taphonomic and local factors. Australian basins, examined using the same methodology showed rather inconsistent results with no obvious amelioration even from the Asselian to the Sakmarian.

\section{Africa}


Although this area has been well-studied from the point of view of sedimentological and geochemical aspects of deglaciation (e.g. Diekmann \& Wopfner 1996, Faure \& Cole 1999, Scheffler et al. 2003, Stollhofen et al. 2000, Visser \& Young 1990, Visser 1995, 1996, 1997; Wopfner 1999) there have been few attempts to relate biotic change to deglaciation, apart from brief references to overall changes in palynomorph assemblages in relation to climate throughout the Permian by Oesterlen \& Millsteed (1994) and Nyambe \& Utting (1997), and a study of the five Ecca Group coal seams of the Witbank Basin, Transvaal, South Africa (Falcon et al. 1984). Though Falcon et al. (1984) did not give a chronostratigraphic age for the Ecca Group, recent radioisotopic dates for the Dwyka and Ecca Groups in the Cape Province and Namibia (Bangert et al. 1999) suggest that the Ecca Group is Asselian - Sakmarian in age, and is therefore of equivalent age to deglacial sequences studied in, for example, Oman. Falcon et al. (1984) suggested that the oldest Witbank seams (Seams No. 1 and 2), were formed soon after the most '...intensive glaciation, characteristic of the Dwyka period'. In similarity with Arabian palynological assemblages of this time, Seam No. 1 is characterised by, amongst others, Microbaculispora tentula Tiwari, and abundant radially and bilaterally symmetrical monosaccate pollen. Seam No. 2 is similar but contains greater numbers of non-taeniate bisaccate pollen, and changes between Seams No. 1 and 2 may therefore be similar to those occurring below the Alisporites indarraensis Biozone of Oman, and the Striatopodocarpites fusus Biozone of the Collie Basin, Western Australia (Backhouse 1991; see later discussion). Falcon et al. (1984) suggested that the floral development of the Witbank area was influenced by the proximity of the sea, and by eustatic fall and rise. They suggested that coalforming periods were associated with regressive periods where large flat coastal lowland areas were available for plant colonisation, though this is inconsistent with 
more recent concepts of sequence stratigraphy that relate coal formation to sea level rise and high water table levels. Relating regression with glacioeustatic sea level fall in this way, they therefore considered coal-forming periods to correspond to shortlived glacial advances during Ecca times, though they considered the main trend through the Ecca to be one of overall climatic amelioration and increase in floral diversity.

There are relatively few studies of Early Permian fauna from southern Africa. Nonmarine arthropod ichnotaxa attributed to crustaceans are reported from the shallow lacustrine Ecca Group that overlies the Upper Dwyka shales (Braddy \& Briggs 2002) and Dickins (1961) reported Eurydesma from the Dwyka beds.

\section{Arabia}

It has long been known that deposits of the Permo-Carboniferous glaciation extended to Oman in the Arabian Peninsular in the form of the Al Khlata Formation. This formation is present in the subsurface in much of the southern part of Oman south of the Oman Mountains and extends northwestward beneath the Rub 'al Khali into Saudi Arabia (Braakman et al. 1982, Levell et al. 1988, Al-Belushi et al. 1996). The distribution of climate-sensitive lithologies within the overlying lower Gharif member of the Gharif Formation sensu Hughes Clarke (1988) indicate that postglacial climate change must have occurred in Oman (Wopfner 1999, Wopfner \& Diekmann 1996). Much of the Al Khlata Formation is composed of glacigenic diamictites. These are succeeded by the Rahab member, which is considered to be a postglacial lacustrine unit (Hughes Clarke 1988, Levell et al. 1988, Wopfner 1999). The lowest lower Gharif member sediments are sandstones and mudstones of probable fluvial origin, 
but above these is a restricted marine interval marked by the acritarch

Ulanisphaeridium omanensis Stephenson \& Osterloff, which is termed the 'maximum flooding shale' (Guit et al. 1995) and represents a possible postglacial eustatic flooding event (Sharland et al. 2001, Stephenson \& Osterloff 2002). Above the 'maximum flooding shale', in the subsurface of south Oman, are beds correlative with the outcropping Saiwan Formation of north central Oman (Guit et al. 1995, Sharland et al. 2001). Angiolini et al. (2003) described faunal evidence for warming within the Saiwan Formation, by observing the development of a pioneer coldwater brachiopod community (Pachycyrtella palaeocommunity) at its base (late early Sakmarian), followed by a more mature secondary ecological community of a wider marine biota of late Sakmarian age. The Pachycyrtella pioneer palaeocommunity records the evolution from glacial to cool temperate climate conditions between the early and late Sakmarian, and colonised the unoccupied environment provided by the sharp transgression at maximum deglaciation (Angiolini et al. 2003). This pioneer palaeocommunity is characterised by (1) random distribution pattern over a limited area, (2) clustering in groups, (3) numerical dominance (> 85\%), (4) suspension feeding, (5) rapid rates of reproduction and growth (r-strategy), (6) early maturity and (7) high mortality rates in the juveniles. The disappearance of the basal palaeocommunity is related to a drastic change in the physical environment, recording the interplay of final Gondwanan deglaciation and initial Neotethys opening (Angiolini et al. 2003). The secondary ecological succession developed rapidly, indicating significant climatic amelioration and more stable environmental conditions (Angiolini et al. 2003). Biodiversity indices significantly increase from the pioneer palaeocommunity (Margalef index 0.2-1.9; Shannon-Wiener index 0.1-1.5; equitability generally $<0.5$ ) to the overlying more mature palaeocommunity 
(Margalef index 1-2.8; Shannon-Wiener index 0.5-2.4; equitability 0.8-1). Climate change continued into middle Gharif member times since that unit contains common calcrete horizons and redbeds (Guit et al. 1995).

The palynological succession within the Rahab and lower Gharif members in well sections Thuleilat (TL)-16 and -42 in south Oman allows detailed metre by metre reconstruction of floral changes within the deglaciation period (Stephenson \& Osterloff 2002, Stephenson et al. 2005). The reconstruction relies on palynomorphs in the sedimentary rocks accurately representing the hinterland vascular plant communities. In broad terms the numbers and variety of palynomorphs are probably an adequate guide to the numbers and variety of plants on the hinterland, but factors such as differing yields of spores and pollen by different plants, and processes such as sorting, may cause taphonomic biases.

In the lowest part of the section (below $940 \mathrm{~m}$ in TL-16 and $944 \mathrm{~m}$ in TL-42; Figs. 2 and 3), a cold climate fern wetland community was present on lowland outwash alluvial plains while on the surrounding uplands or better-drained ground, a primitive conifer community developed (Stephenson \& Osterloff 2002, Stephenson et al. 2005). There is also evidence that a specialised autochthonous freshwater algal palaeoecology occupied small ponds in the fern lowland wetland environment. Later in the postglacial period (above $940 \mathrm{~m}$ in TL-16 and $944 \mathrm{~m}$ in TL-42), these communities were replaced. In the lowland alluvial plains, a cycad-like and lycopsid vegetation developed, while in the uplands or better drained areas a taeniate- and nontaeniate bisaccate pollen producing glossopterid or other gymnospermous flora was established. Later (above $925 \mathrm{~m}$ in TL-16 and $915 \mathrm{~m}$ in TL-42), restricted marine conditions occurred in parts of the sedimentary basin; within the bodies of brackish or 
salt water, an ephemeral microflora and fauna (indicated by rare acritarchs and microforaminiferal linings) developed. This restricted marine transgression probably advanced from the northeast (Konert et al. 2001) and may represent the first major deglacial eustatic sea level rise of the Permian in the Arabian region (Stephenson \& Osterloff 2002, Stephenson et al. 2005).

A carbon isotope record from organic matter within the same sections of the Al Khlata and lower Gharif formations of TL-16 and -42 show a $\delta^{13} \mathrm{C}_{\text {organic }}$ trend from-21 to $-24 \%$ (Stephenson et al. 2005; Figs. 2 and 3). The trend may be due to changes in palaeoatmospheric $\mathrm{CO}_{2}$ since they cannot be accounted for by changes in organic matter type or preservation. Changing ${ }^{13} \mathrm{C} /{ }^{12} \mathrm{C}$ ratios in atmospheric $\mathrm{CO}_{2}$ are known to occur in response to changes in the proportions of carbonate and organic carbon 'burial' (Erwin 1993), and between glacial and interglacial environments due to changes in biomass and productivity (Arens et al. 2000). The decreasing trend seen in TL-16 and TL-42 may therefore represent change in the carbon cycle although it is impossible to identify a specific mechanism.

\section{Australia}

The Early Permian of Australia is perhaps the most intensively studied of the former parts of Gondwana, but comparatively few studies address the biotic response to Asselian-Sakmarian deglaciation. After his pioneering work in the 1970s and 1980s, Dickins (1993) summarised the faunal succession of Western Australia in relation to climatic warming in broad terms. Glacial features are present in the Nangetty Formation of the Perth Basin, the Lyons Group of the Carnarvon Basin, and the Grant Group and Paterson Formation of the Canning Basin. Intercalated with, and overlying 
these, are rocks containing a cold water marine fauna consisting of the bivalves Eurydesma and Deltopecten, the gastropod Keeneia, and the brachiopods Lyonia lyoni (Prendergast), Rhynchopora australasica Archbold, Kiangsiella sp., Grumantia cf. costellata Clarke, Cyrtella australis Thomas, Ambikella notoplicata Archbold \& Thomas and Trigonotreta lyonsensis Archbold \& Thomas. Dickins (1985) recognized five glacial/interglacial phases in the Lyons Group, with the intercalated marine fauna remaining relatively uniform throughout its deposition and indicative of cold water. Above this, in the Fossil Cliff Member of the Holmwood Shale (Perth Basin), the Callythara Formation (Carnarvon Basin) and the Nura Nura Member of the Poole Sandstone (Canning Basin) there is a more diverse, slightly warmer water fauna, including brachiopods, bryozoans, blastoids and crinoids. Amongst the bivalves, Dickins (1993) considered the bivalve Edmondia to indicate warm conditions. Archbold (1998) revised the faunal succession of Western Australia and showed an increase in biodiversity from the Asselian Lyonia lyoni Biozone (7 species), through the Tastubian (early Sakmarian) Trigonotreta occidentalis Biozone (10 species) to the Sterlitamakian (late Sakmarian) Coronalosia irwinensis (formerly Strophalosia irwinensis) Biozone (40 species). There is a slow trend in increase of biodiversity between the first two biozones (Asselian to Tastubian in age), but a sudden shift occurs in the Sterlitamakian Coronalosia irwinensis Biozone. This biotic change is consistent with the water temperature curve established by Archbold \& Shi (1995) and based on the presence/absence of Tethyan brachiopod genera, which are considered indicators of warm water. According to this curve, cold water temperatures $\left(5^{\circ} \mathrm{C}\right)$ in the Lyonia lyoni Biozone evolved to warmer temperatures $\left(20^{\circ} \mathrm{C}\right)$ in the Coronalosia irwinensis Biozone, which is characterised by high biodiversity and by the invasion of a significant number of Tethyan genera (about 14). 
Also oxygen isotope data available for Lower Permian Australian spiriferids (Compston 1960, Lowenstam 1961, 1964) indicate the potential for a significant temperature change during Asselian-Tastubian times and late Artinskian times.

In recent reviews of the palaeobiogeography of Australasian brachiopod faunas, Archbold $(2000,2001)$ demonstrated the striking difference in generic and specific composition of brachiopods on either side of the continent. The eastern side of Australasia was affected by cold water currents: eastern Australia marine faunas have a strong link with New Zealand and New Caledonia and a lower diversity than coeval Western Australian (westralian) faunas. They show an increase in biodiversity from south (Tasmania) to north (Bowen Basin, Queensland) which is interpreted as reflecting an increase in temperature from cold to cool temperate. Clarke (1990) illustrated brachiopod and bivalve assemblages from glendonite bearing siltstones above the glacigene sequence in Tasmania and interpreted these as cold-water low diversity faunas.

The eastern Australian brachiopod biozonation of Briggs (1998) shows a slight increase in the number of taxa from the Asselian Lyonia bourkei Biozone to the Tastubian Strophalosia concentrica and Strophalosia subcircularis biozones with a reverse trend in the Sterlitamakian Bandoproductus walkomi Biozone. A significant increase in diversity is recorded later, in the lower Artinskian Echinalosia curtosa Biozone. This biotic change is consistent with persistence of cold climate and glaciation in eastern Australia during the late Sakmarian (Frank et al. 2005). In palynological terms few deglaciation sequences have been studied to the same level of detail as the Rahab and Lower Gharif members of Oman, hence close comparisons 
are not possible. However, sequences in Western Australia studied by Backhouse (1991) allow some comparison. Backhouse (1991) noted decreases in monosaccate pollen and later increases in small bisaccate pollen within and just above a section assignable to the Granulatisporites confluens Biozone of Foster \& Waterhouse (1988). Backhouse (pers. comm., 2000) considered the bisaccate pollen to be closely similar to Alisporites indarraensis Segroves. No Ulanisphaeridium omanensisbearing horizon was reported by Backhouse (1991) though the low sample frequency of Backhouse's study may not have been sufficient to detect such a narrow horizon.

Lithostratigraphic similarities between the deglaciation sequences in Oman and the Canning Basin, Western Australia have been noted by Wopfner (1999). The scarcity of palynological information from the Canning Basin sequences does not allow close comparison, but it is notable that the acritarch Ulanisphaeridium berryense McMinn, a taxon closely similar to $U$. omanensis was recorded by Foster \& Waterhouse (1988) from the upper parts of the sequence assigned to the $G$. confluens Biozone in Calytrix No. 1 well in the Canning Basin.

\section{India}

It has long been known that the dominantly continental Early Permian strata of the lower Talchir Formation and overlying Karharbari Formation (Indian Peninsular) contain both glacigene diamictites (Ghosh \& Mitra 1972, Frakes et al. 1975) and thin marine intercalations (Sastry \& Shah 1964). Shah \& Sastry (1975) considered the marine beds at Manendragarh and Rajhara to be within the lower and middle parts of the Talchir Formation, and those at Umaria and Badhaura to be in the basal part of the Karharbari Formation. They further considered the two sets of marine beds to have 
been deposited by separate transgressions, the earlier in the Asselian, the later in the Sakmarian. However, Frakes et al. (1975) considered there to be no difference in the faunas at Umaria and Manendragarh and assumed them to be of the same age, being characterised chiefly by the shelly fauna Eurydesma, Peruvispira and Trigonotreta. Dickins \& Shah (1979) supported the view of Shah \& Sastry (1975) and reported a list of foraminifers, bryozoans, brachiopods, bivalves, gastropods and crinoids from Manendragarh and Umaria suggesting correlation to the Lyons Group marine faunas of Western Australia. The more diversified marine fauna from Badhaura, with more than 17 brachiopod species, is considered younger and correlateable to the Callytharra Formation of Western Australia. According to Archbold et al. (1996), the Manendragarh brachiopod fauna is characterized by Trigonotreta hesdoensis (Sahni and Dutt), which is one of the most primitive species of the genus (Angiolini et al. 2005). Slightly younger (late Tastubian) is Trigonotreta narsarhensis (Reed); a later evolutionary form of $T$. hesdoensis) from Umaria which is associated with Bandoproductus umariensis (Reed), Arctitreta sp., Tomiopsis barakerensis (Reed) (= Ambikella) and Cleiothyridina sp. The Badhaura fauna is more diversified containing species of the genera Semilingula, Arctitreta, Derbyia, Strophalosia, Aulosteges, Cyrtella, Neospirifer, Crassispirifer, Ambikella, Hoskingia, Fletcherithyris and Gilledia and is considered to be at least Sterlitamakian in age by Archbold et al. (1996). Apart from the discussion of Dickins (1985) who recognized the Umaria beds as representing the Tastubian post glacial eustatic rise, no attempt has been made to link the biotic change with the post glacial climatic change in India.

Venkatachala \& Tiwari (1987) suggested that other marine intervals could be identified within the Talchir Formation on the basis primarily of palynomorphs such 
as acritarchs and leiospheres. Although no detailed attempts have been made to link climate change with macrofaunal and macrofloral change through the Talchir and Karharbari formations, palynomorphs have been studied with this aspect in mind (e.g. Banerjee \& D’Rozario 1990, Pant 1996, Tiwari 1994, Venkatachala et al. 1995, Vijaya 1994, Vijaya et al. 2001). The most detailed of these studies in relation to the Early Permian is that of Vijaya (1994). Within the Talchir Formation, Vijaya (1994) recognised three phases recording an upsection increase in microfloral diversity. The earliest of these (Phase I, considered of Asselian age) is characterised by common radially- and bilaterally-symmetrical monosaccate pollen and simple trilete spores. Phase II is characterised by sculptured monosaccate pollen, taeniate bisaccate pollen and more common sculptured spores. Finally, Phase III, considered of early Sakmarian age, is characterised by a maximum diversity of forms. Vijaya (1994) considered Phase III to correlate with the Granulatisporites confluens Biozone. These palynological changes cannot be directly related to facies changes in a single section, since Vijaya (1994) presents the data in a generalised way, but clearly the sequence is deglacial in form and has some similarity with palynological changes recorded elsewhere in Gondwana. Similar phases, attributed to climatic warming were also suggested by Banerjee \& D'Rozario (1990).

\section{Antarctica}

Late Palaeozoic rocks of glacial origin outcrop in the central Transantarctic Mountains, Victoria Land and the Ellsworth Mountains of west Antarctica. Isbell \& Cúneo (1996) demonstrated rapid change from glacigene to sediments of post glacial origin within the Weller Coal Measures of southern Victoria Land. In an investigation of the palaeoenvironment of the Weller Coal Measures, Francis et al. (1993) 
considered that winter temperatures were low during deposition, suggesting that adjacent uplands were probably still glaciated. They also suggested that summer temperatures were nevertheless adequate for a peat-forming flora and forest vegetation (evidenced from very large in situ Glossopteris stumps). The forests may have been deciduous (Taylor et al. 1992) reflecting such seasonality, and the leaves of Glossopteris are often found in thick mats (Francis et al. 1993). The age of the Weller Coal Measures and underlying diamictites, and therefore of the date of this rapid deglaciation, are uncertain however, and can only be placed between Eastern Australian Palynological Stage 2 (see Evans 1969, Barrett \& Kyle 1975) and Stage 4 (Kyle 1977). Thus the deglaciation cannot be directly correlated with others in for example Oman and the Collie Basin, Western Australia.

Lindström (1995), however, showed detailed palynological changes occurring within the Granulatisporites confluens Biozone in rocks in western Dronning Maud Land. She correlated these changes with the lower Weller Coal Measures and the underlying Darwin Tillite and considered the rocks to have been deposited in a cold climate, not far from active glaciation. The sections Lindström (1995) studied were stratigraphically rather short (both less than $10 \mathrm{~m}$ ) and so probably represent a 'snapshot' of climate change, but some of the changes are consistent with those noted in Oman, Peninsular India and Western Australia. At Lindström's Locality A, for example, the highest samples are dominated by non-taeniate bisaccate pollen, whilst monosaccate pollen dominate the lower part of the section. Granulatisporites confluens occurs throughout, apart from two sample levels toward the centre of the section.

Few Early Permian macrofossils have been described from Antarctica. Kelly et al. 
(2001) reported Cancrinella sp. in bioturbated mudstones from locality B at Alexander Island (Antarctic Peninsula) which according to Archbold et al. (2004) is comparable to Costatumulus sp. B. of the Rio Blanco basin Association II (Argentina) and given a middle-late Asselian age.

\section{Farfield isotope and atmospheric studies}

There are relatively few studies using isotopes which are specific to the Early Permian; but there are low resolution isotope curves which record sea water composition for most of the Phanerozoic based on compilations of the carbon and oxygen isotope composition of brachiopods (e.g. Veizer et al. 1999). Through the Phanerozoic, changes in marine $\delta^{13} \mathrm{C}$ are interpreted in terms of global changes in burial and re-oxidation of organic matter; although other processes such as release of low $\delta^{13} \mathrm{C}$ volcanic or mantle $\mathrm{CO}_{2}$ into the atmosphere, discharges of oceanic methane and overturn of low $\delta^{13} \mathrm{C}$ anoxic bottom waters are all described (Korte et al. 2005). Variation in $\delta^{18} \mathrm{O}$ in brachiopod shells is thought to be largely due to the growth and retreat of continental glaciers, although multimillion-year variations in $\delta^{18} \mathrm{O}$ may also be a function of interactions of the oceans with the lithosphere driven by tectonics (e.g. Veizer et al. 1997). The Phanerozoic seawater curves show that in the Early Permian there was a rapid decline in $\delta^{18} \mathrm{O}$ despite the curve for $\delta^{13} \mathrm{C}$ being rather flat (Veizer et al. 1999). The only dedicated Permian isotope seawater curves are based on a compilation of data from brachiopods from a series of discrete basins. The $\delta^{18} \mathrm{O}$ data show this decline of 2.5\% in the Early Permian (Asselian to late Artinskian) (Fig. 5, see also Korte et al. 2005), over a time span of 10 my. The study of Korte et al. (2005) is also one of few that describes rigorous screening of brachiopod carbonate 
data for diagenetic alteration using a combination of microtextural and trace element content. However, the Early Permian brachiopod data given in Korte et al. (2005) are entirely derived from the southern Urals (sections from Usolka, Sakmara and Dalnij Tyulkas; references in Korte et al. 2005). The southern Urals were palaeoequatorial at this time, and therefore climatically distinct from the cold climate seas in which most post glacial Gondwanan brachiopods lived. However, Korte et al. (2005) assumed that southern Urals brachiopods lived in basins that were open to the Palaeotethys Ocean, and so were capable of reflecting a global signal. Korte et al. (2005) considered a 2\%o spread in both $\delta^{13} \mathrm{C}$ and $\delta^{18} \mathrm{O}$ in coeval brachiopods as sufficient to allow for global differences including variations in seawater temperature with latitude (Brand et al. 2003, James et al. 1997). Korte et al. (2005) therefore assumed that the decline in $\delta^{18} \mathrm{O}$ in the Early Permian Urals brachiopods is a global signature and not a geographical artefact, so that the data can represent far-field evidence to help decipher changing environment around Gondwana. In general the $\delta^{13} \mathrm{C}$ data in the Early Permian are stable around $+4.3 \%$. In contrast the $\delta^{18} \mathrm{O}$ data from the Asselian and lower Sakmarian brachiopods have values between +0.1 to $-2.3 \%$ (the latter being the highest of all the values throughout the Permian); values drop to $-3.5 \%$ in the late Artinskian. Korte et al. (2005) considered that the most likely cause for this decline in $\delta^{18} \mathrm{O}$ is the return of isotopically light waters to the oceans from melting of Permian glaciers at high latitudes (Fig. 5). This explanation is not entirely consistent with evidence from brachiopods and palynology (see earlier discussion), because that suggests deglaciation was confined to the Asselian and Sakmarian. Given that the Late Palaeozoic and Pleistocene glaciations were probably of similar magnitude (Crowley and Baum 1992), it has been calculated that we can ascribe an approximate 
$2.3 \%$ increase in seawater $\delta^{18} \mathrm{O}$ to the 'ice volume effect' (Korte et al. 2005). The maximum range in data we see over this period is $3.6 \%$ o $(+0.1 \%$ to $-3.5 \%$ shown on fig. 7 of Korte et al. 2005). Therefore the remaining $1.3 \%$ in $\delta^{18} \mathrm{O}$ could be caused by an increase in temperature of approximately $5^{\circ} \mathrm{C}$ in the Urals. Korte et al. (2005) concluded therefore that the decline of the Gondwana ice sheet was due to global warming because of the requirement for both temperature and ice volume to explain the $\delta^{18} \mathrm{O}$ variation.

Another Early Permian farfield temperature change reconstruction from a study of oxygen and hydrogen isotope ratios in pedogenic phyllosilicates is that of Tabor \& Montañez (2005). The Midland Basin of Texas and the southern Anadarko Basin of Oklahoma were equatorial during the Early Permian. The phyllosilicates have $\delta \mathrm{D}$ and $\delta^{18} \mathrm{O}$ values that are thought to represent Early Permian meteoric waters at a specific temperature. Using the mineral-water temperature dependent fractions equations it was shown that the palaeotemperature of phyllosilicate crystallisation ranged from $22+/-3^{\circ} \mathrm{C}$ to $35+/-3^{\circ} \mathrm{C}$ (calcite $\delta^{18} \mathrm{O}$ data) across the Carboniferous - Permian boundary in the East Midland basin.

One of the few open marine isotope records from the Early Permian has been reported from the Karoo Basin, South Africa (Scheffler et al. 2003). The basin contains organic matter thought to be almost entirely of marine origin, and this was measured for $\delta^{13} \mathrm{C}$. The $\delta^{13} \mathrm{C}$ composition of marine organic matter is often thought to reflect the $\delta^{13} \mathrm{C}$ signature of atmospheric $\mathrm{CO}_{2}$ and therefore reflect changes in $\mathrm{pCO}_{2}($ Scheffler et al. 2003). The lowest $\delta^{13} \mathrm{C}$ values therefore represent full glacial conditions, while deglaciation is represented by higher $\delta^{13} \mathrm{C}$. The Karoo Basin has $\delta^{13} \mathrm{C}_{\text {organic }}$ which 
increases $(<-25 \%$ o to $-22 \%$ ) from 308 to $288 \mathrm{Ma}$, a trend that Scheffler et al. (2003) compared to Veizer et al.'s (1999) $\delta^{13} \mathrm{C}$ data from equatorial shelly carbonates for the same time period. The trend to increasing $\delta^{13} \mathrm{C}$ values in both the Karoo organic matter and equatorial carbonates is thought to represent the same global $\mathrm{pCO}_{2}$ shift. The Ecca Group which has the highest $\delta^{13} \mathrm{C}_{\text {organic }}$ values is thought to have been, at least in part, deposited during the earliest Asselian.

\section{Further study}

The Early Permian rocks of Gondwana that can be related to climate-forced deglaciation are well represented sequences of pre-Cainozoic glaciation, and therefore form an invaluable resource to develop a Gondwana biotic deglaciation model. The advantages of developing such a deglaciation model would be in understanding the response of life to increasing temperatures and other climate change, and might be useful in the study of modern biotic change during global warming. However to achieve such a model a number of factors need to be considered:

1. More detailed bed by bed interdisciplinary palaeontological studies of measured sections demonstrably related to climate-forced deglaciation must be carried out. Clearly such studies are limited to sections with well-preserved fossils and more or less continuous stratigraphical fossil occurrence. While this may be possible for palynology, it is unlikely to be possible for macrofossils, which in post glacial Early Permian sequences are stratigraphically and geographically rather isolated. Palynological assemblages that are defined quantitatively would be likely to be important in such studies, but such assemblages at least in glacigene sediments, have been shown to be influenced by facies (Stephenson 1998), and reworking 
(Osterloff et al. 2004). Similarly, factors related to differential spore or pollen production by different plants can influence the quantitative characteristics of palynological assemblages (Wilson 1963), as can overrepresentation of natural diversity due to excessive taxonomic splitting. Thus study of biotic change needs to compensate for such factors.

2. Sections for study must be coeval so that similarities (due to general climate change) and differences (presumably due to local responses to deglaciation) can be distinguished. However establishing isochroneity is very difficult, and it is likely that palynological data will be required to correlate sequences - while also defining climate change - so there will be attendant problems of circularity of argument. An advantage of establishing a Gondwana-wide palynostratigraphy, uniting the four or five schemes presently in existence for the former continents of Gondwana would also be in allowing other palaeontological data, of which there are considerable amounts, to be used. It is also possible that final glacial events may be of slightly different ages in different places. This has already been established on a large scale, since glaciation in southeast Australia can be shown to have persisted into the Artinskian, but also there may be variations in periods of maximum rate of biotic change from region to region, due to differing palaeolatitudes, for example. Finally many of the postglacial sequences for which only palynological information is available are mainly non-marine, for example in India and Arabia. Non-marine glacial basins are known for numerous disconformities and non sequences, and for large-scale cyclical reworking of older sediments. It may not always be possible, even under the best biostratigraphical circumstances to be able to correlate such rocks across a large continent. 


\section{Conclusions}

1. The Early Permian rocks of Gondwana that can be related to climate-forced deglaciation are perhaps the best known and best represented sequences of pre Cainozoic glaciation, and therefore form an invaluable resource for future research, to develop a Gondwana biotic deglaciation model.

2. Present data, which is widely scattered geographically and of different stratigraphic scales and resolutions, clearly show diversity increase from glacial conditions to post glacial conditions.

3. Amongst the marine fauna, a cold water marine fauna consisting of bivalves such as Eurydesma and Deltopecten, and brachiopods such as Lyonia were established in the earliest post glacial marine transgressions that did not affect all of Gondwana. Above this is a more diverse, slightly warmer cold temperate fauna, including brachiopods, bryozoans, blastoids and crinoids like those of the Haushi Limestone of Oman. A summary of marine faunal and palynological changes in Gondwanan Early Permian deglaciation sequences is shown in Figure 4.

4. The palynomorph succession, which covers the deglaciation period more fully, shows some consistency across Gondwana in Asselian-Sakmarian rocks. Very broadly, a change from monosaccate pollen assemblages, associated with fern spores to more diverse assemblages with common non-taeniate bisaccate pollen occurs through the deglaciation period (Fig. 4). In Oman, where this has been studied in greatest detail, the upland saw changes from a glacial monosaccate pollen-producing flora to a warmer climate bisaccate pollen-producing flora; in the lowlands, a parallel change occurred from a glacial fern flora to a warmer 
climate colpate pollen-producing and lycopsid lowland flora. The sedimentary organic matter of the clastic rocks of the sequence records a corresponding $\delta^{13} \mathrm{C}$ trend (from approximately -21 to $-24 \%$ ) believed to reflect palaeoatmospheric change due to postglacial global warming.

5. Of the few Early Permian farfield isotope studies, the most detailed (Korte et al. 2005) compiled from brachiopods from the southern Urals, shows a $\delta^{18} \mathrm{O}$ decline of $2.5 \%$ in the Early Permian (Asselian to Artinskian) and stable $\delta^{13} \mathrm{C}$ values of around $+4.3 \%$ in the same period. This farfield evidence is in part consistent with Gondwanan palaeontological data since the most likely cause for the decline in $\delta^{18} \mathrm{O}$ is the return of isotopically light waters to the oceans from melting of glaciers at high latitudes.

M. H. Stephenson and M. J. Leng publish with permission of the Director of the British Geological Survey. The authors thank Elsevier Publishing for permission to reproduce figures 6 and 8 from Korte et al. (2005) and the Geological Society for permission to reproduce figures 4 and 5 from Stephenson et al. (2005).

\section{References}

Al-Belushi, J. D., Glennie, K. W. \& Williams, B. P. J. 1996. Permo-Carboniferous Glaciogenic Al Khlata Formation, Oman: a new hypothesis for origin of its glaciation. 
GeoArabia, 1, 389-404.

Anderson, J. M. 1977. The biostratigraphy of the Permian and Triassic. Part 3. A review of Gondwana Permian palynology with particular reference to the northern Karroo Basin of South Africa. Memoirs of the Botanical Survey of South Africa, 41, $1-133$

Angiolini, L., Balini, M., Garzanti, E., Nicora, A., \& Tintori, A. 2003. Gondwanan Glaciation and opening of Neotethys: the Al Khlata and Saiwan formations of Interior Oman. Palaeogeography, Palaeoclimatology, Palaeoecology, 196, 99-123.

Angiolini L., Crasquin-Soleau S., Platel J.-P., Roger J., Vachard D., Vaslet D. \& Al Husseini M. 2004. Saiwan, Gharif and Khuff formations, Haushi-Huqf Uplift, Oman. In: Al-Husseini, M. I. (ed.), Carboniferous, Permian and Triassic Arabian Stratigraphy. GeoArabia Special Publication 3, Gulf PetroLink, Manama, Bahrain, 149-183.

Angiolini, L., Brunton, H. \& Gaetani, M. 2005. Early Permian (Asselian) brachiopods from Karakorum (Pakistan) and their palaeobiogeographical significance.

Palaeontology, 48, 69-86.

Angiolini, L., Bucher, H., Pillevuit, A., Platel, J-P., Roger, J., Broutin, J., Baud, A., Marcoux, J. \& Al-Hashmi, H. 1997. Early Permian (Sakmarian) Brachiopods from southeastern Oman. Geobios, 30, p. 379-405.

Angiolini, L., Stephenson, M H \& Leven, Y. 2006. Correlation of the Lower Permian surface Saiwan Formation and subsurface Haushi Limestone, central Oman.

GeoArabia, 11, 17-38. 
Apak, S. N. \& Backhouse, J. 1999. Stratigraphy and petroleum exploration objectives of the Permo-Carboniferous sucession on the Barbwire Terrace and adjacent areas, northewest Canning Basin, Western Australia. Geological Survey of Western Australia, Report, 68, 30pp.

Archangelsky, S. 1990. Plant distribution in Gondwana during the Late Palaeozoic. In: Taylor, T. N. \& Taylor, E. L. (eds) Antarctic Paleobiology. Springer Verlag, New York, 102-117.

Archangelsky, S., Azcuy, C. L., Pinto, I. D., González, C. R., Marques-Toigo, M., Rösler, O. \& Wagner, R. H. 1980. The Carboniferous and Early Permian of the South American Gondwana area: a summary of the biostratigraphic information. Actas del II Congreso Argentino de Paleontología y Bioestratigrafía y I Congreso Latinoamericano de Paleontología 1978, 4, 257-269.

Archbold, N. W. 1998. Marine biostratigraphy and correlation of the west Australian Permian basins. In: Purcell, P. G. \& Purcell, R. R., (eds) The sedimentary basins of Western Australia 2, Proceedings of the Petroleum Exploration Society of Australia Symposium, Perth, Western Australia 1998, 141-151.

Archbold, N.W 1999. Permian Gondwana correlations: the significance of the western Australian marine Permian. Journal of African Earth Sciences, 29, 63-75.

Archbold, N. W. 2000. Palaeobiogeography of the Australasian Permian. Memoir of the Association of Australasian Palaeontologists, 23, 287-310.

Archbold, N. W. 2001. Pan-Gondwanan, Early Permian (Asselian-SakmarianAktastinian) correlations. In: Weiss, R. E. (ed.) Contributions to geology and 
paleontology of Gondwana - in honour of Helmut Hopfner. Geological Institute, University of Cologne, 29-39.

Archbold, N. W. \& Dickins, J. M. 1996. Permian (Chart 6). In: Young, G. C. \& Laurie, J. R. (eds) An Australian Phanerozoic timescale. OUP, Melbourne, 127-135.

Archbold, N. W. \& Shi, G. R. 1995. Permian brachiopod faunas of Western Australia: Gondwanan-Asian relationships and Permian climate. Journal of Southeast Asian Earth Sciences, 11, 207-215.

Archbold, N. W., Cisterna, G. A. \& Simanauskas, T. 2004. The Gondwanan Carboniferous-Permian boundary revisited: new data from Australia and Argentina. Gondwana Research, 7, 125-133.

Archbold, N. W., Shah, S. C. \& Dickins, J. M. 1996. Early Permian brachiopod faunas from Peninsular India: their Gondwanan relationships. Historical Biology, 11, $125-135$.

Arens, N. C., Hope Jahren, A. \& Amundson, R. 2000. Can C3 plants faithfully record the carbon isotope composition of atmospheric carbon dioxide? Paleobiology, 26, $137-164$.

Azcuy, C. L. 1979. A review of the early Gondwana palynology of Argentina and South America. IV International Palynological Conference, Lucknow, India 1976, Birbal Sahni Institute Lucknow, India, 2, 175-185.

Azcuy, C. L. \& Jelin, R. 1980. Las palinozonas del limite Carbónico-Pérmico en la Cuenca Paganzo. Actas II Congreso Argentina de Palaeontologia y Bioestratigrafia y I Congreso Latinoamericano de Palaeontologia, 4, 51-67. 
Backhouse, J. 1991. Permian Palynostratigraphy of the Collie Basin, Western Australia. Review of Palaeobotany and Palynology, 67, 237-314.

Banerjee, M. \& D'Rozario, A. 1990. Palynostratigraphic correlation of Lower Gondwana Sediments in the Chuparbhita and Hura basins, Rajmahal Hills, Eastern India. Review of Palaeobotany and Palynology, 65, 239-255.

Bangert, B., Stollhofen, H., Lorenz, V. \& Armstrong, R. 1999. The geochronology and significance of ash-fall tuffs in the glaciogenic Carboniferous-Permian Dwyka Group of Namibia and South Africa. Journal of African Earth Sciences, 29, 33-49.

Banks, M. R. \& Clarke, M. J. 1987. Changes in the geography of the Tasmania Basin on the Late Paleozoic. In: McKenzie, G. D. (ed.) Gondwana Six: stratigraphy, sedimentology and paleontology, Washington D.C. American Geophysical Union, 114.

Barrett, P. J. \& Kyle, R. A. 1975. The Early Permian glacial beds of South Victoria Land and the Darwin Mountains, Antarctica. In: Campbell, K.W. (ed.) Gondwana Geology, Australian National University Press, Canberra, 1975, 333-346.

Bharadwaj, D. C. 1969. Lower Gondwana Formations. 6th Congress of the Stratigraphy and Geology of the Carboniferous, Sheffield 1967. Compte Rendu, 1, 255-274.

Braakman, J., Levell, B., Martin, J., Potter, T. L. \& Van Vliet, A. 1982. Late Palaeozoic Gondwana glaciation in Oman. Nature, 299, 48-50.

Braddy S. J. \& Briggs D. E. G. 2002. New Lower Permian nonmarine arthropod trace fossils from New Mexico and South Africa. Journal of Paleontology, 76, 546-557. 
Brand, U., Logan, A., Hiller, N. \& Richardson, J. 2003. Geochemistry of modern brachiopods: applications and implications for oceanography and paleoceanography. Chemical Geology, 198, 305-334.

Briggs, D. J. C. 1998. Permian Productidina and Strophalosiidina from the SydneyBowen Basin and New England Orogen: systematics and biostratigraphic significance. Memoir of the Association of Australasian Palaeontologists, 19, 1-258.

Césari, S. N. \& Gutiérrez, P. R. 2000. Palynostratigraphy of Upper Palaeozoic sequences in central-western Argentina. Palynology, 24, 113-146.

Chandra, S. K. 1994. Marine signatures in the Gondwanas of Peninsular India and Permian palaeogeography. Ninth International Gondwana Symposium, Hyderabad, India, January, 1994, 529-538.

Charrier, R. 1986. The Gondwana glaciation in Chile: description of alleged glacial deposits and palaeogeographic conditions bearing on the extension of the ice cover in southern South America. Palaeogeography, Palaeoclimatology, Palaeoecology, 56, $151-175$.

Cisterna G. A. \& Simanauskas T. 2000. Brachiopods from the Rio del Penon Formation, Rio Blanco Basin, Upper Palaeozoic of Argentina. Revista Española de Paleontología, 15, 129-151.

Cisterna G. A., Simanauskas T. \& Archbold N. W. 2002a. Permian brachiopods from the Tupe Formation, San Juan Province, Precordillera, Argentina. Alcheringa, 26, 177-200.

Cisterna G. A., Simanauskas T. \& Archbold N. W. 2002b. The Permian brachiopod 
genus Trigonotreta Koening and its occurrence in Argentina. Ameghiniana, 39, 213220.

Clarke M. J. 1990. Late Palaeozoic (Tamarian; Late Carboniferous-Early Permian) cold water brachiopods from Tasmania. Alcheringa, 14, 53-76.

Closs, D. 1970. Intercalation of goniatites in the Gondwanic glacial beds of Uruguay. Gondwana Stratigraphy, 1st Gondwana Symposium, Buenos Aires, 1967, UNESCO, Earth Sciences, 2, 197-202.

Compston W. 1960. The Carbon isotopic composition of certain marine invertebrates and coals from the Australian Permian. Geochimica et Cosmochimica Acta, 18, 1-22.

Cousminer, H. L. 1965. Permian spores from Apillapampa, Bolivia. Journal of Paleontology, 39, 1097-1111.

Crowell, J. C. 1995. The ending of the Late Paleozoic ice age during the Permian paper. In: Scholle, P. A., Peryt, T. M. \& Ulmer-Scholle, D. S. (eds) The Permian of Northern Pangea Vol. 1. Palaeogeography, Palaeoclimates, Stratigraphy. Springer Verlag, 62-74.

Crowley, T. J. \& Baum, S. K. 1992. Modelling late Paleozoic glaciation. Geology, 20, $507-510$

Dickins, J. M. 1957. Lower Permian pelecypods and gastropods from the Carnarvon Basin, Western Australia. Australian Bureau of Mines and Mineral Resources Bulletin, 41, 75pp.

Dickins, J. M. 1961. Permian pelecypods newly recorded from eastern Australia. Palaeontology, 4, 119-130. 
Dickins, J. M. 1978. Climate of the Permian in Australia: the invertebrate faunas. Palaeogeography, Palaeoclimatology, Palaeoecology, 23, 33-46.

Dickins, J. M. 1984. Evolution and climate in the Upper Palaeozoic. In: Brenchley, P. (ed.) Fossils and Climate. John Wiley and Sons, Chichester, 317-327.

Dickins, J. M. 1985. Late Palaeozoic glaciation. Bureau of Mines and Mineral Resources Journal of Australian Geology and Geophysics, 9, 163-169.

Dickins, J. M. 1992. Permian geology of Gondwana countries: a review. International Geology Reviews, 34, 986-1000.

Dickins, J. M. 1993. Palaeoclimate. In: Skwarko, S. K. (ed.) Palaeontology of Western Australia. Geological Survey of Western Australia Bulletin, 135, 7-9.

Dickins, J. M. 1996. Problems of a Late Palaeozoic glaciation in Australia and subsequent climate in the Permian. Palaeogeography, Palaeoclimatology, Palaeoecology, 125, 185-197.

Dickins J. M. \& Shah S. C. 1979. Correlation of the Permian marine sequence of India and Western Australia. In: Laskar, B. \& Raja Rao, C. S. (eds) Fourth International Gondwana Symposium, Papers, vol. II. Delhi, Hindustan Publishing Corporation, India, 387-408.

Diekmann, B. \& Wopfner, H. 1996. Petrographic and diagenetic signatures of climate change in peri- and postglacial Karoo sediments of SW Tanzania. Palaeogeography, Palaeoclimatology, Palaeoecology, 125, 5-25.

Erwin, D. H. 1993. The Great Paleozoic Crisis: life and death in the Permian. 
Columbia University Press, New York, 327 pp.

Evans, P. R. 1969. Upper Carboniferous and Permian palynological stages and their distribution in eastern Australia. In: Gondwana Stratigraphy, IUGS Symposium Argentina (1967), UNESCO, Earth Sciences, 2, 41-54.

Eyles, N. \& de Broekert, P. 2001. Glacial tunnel valleys in the Eastern Goldfields of Western Australia cut below the Late Paleozoic Pilbara ice sheet. Palaeogeography, Palaeoclimatology, Palaeoecology, 171, 29-40.

Eyles, N. \& McCabe, A. M. 1989. The Late Devensian (<22000 YBP) Irish Sea Basin: the sedimentary record of a collapsed ice sheet margin. Quaternary Science Reviews, 8, 307-351.

Eyles, N., Eyles, C. H. \& Gostin, V. A. 1997. Iceberg rafting and scouring in the Early Permian Shoalhaven Group of New South Wales, Australia: evidence of Heinrich-like events? Palaeogeography, Palaeoclimatology, Palaeoecology, 136, 117.

Eyles, C. H., Eyles, N. and Gostin, V. A. 1998. Facies and allostratigraphy of highlatitude, glacially influenced, marine strata of the Early Permian southern Sydney Basin, Australia. Sedimentology, 45, 121-161.

Eyles, N., Mory, A. J. \& Backhouse, J. 2002. Carboniferous-Permian palynostratigraphy of west Australian rift basins: resolving tectonic and eustatic controls during Gondwanan glaciations. Palaeogeography, Palaeoclimatology, Palaeoecology, 184, 305-319.

Falcon, R. M. S. 1975. Palynostratigraphy of the Lower Karroo sequence in 
Sebungwe District, Mid Zambezi Basin, Rhodesia. Palaeontologia Africana, 18, 1-29.

Falcon, R. M. S., Pinheiro, H. \& Sheperd, P. 1984. The palynobiostratigraphy of the major coal seams in the Witbank Basin with lithostratigraphic, chronostratigraphic and palaeoclimatic implications. Comunicações dos Serviços Geológicos de Portugal, 70, 215-243.

Farabee, M. J., Taylor, E. L. \& Taylor, T. N. 1991. Late Permian palynomorphs from the Buckly Formation, central Transantactic Mountains, Antarctica. Review of Palaeobotany and Palynology, 69, 353-368.

Faure, K. \& Cole, D. 1999. Geochemical evidence for lacustrine microbial blooms in the vast Permian main Karoo, Paraná, Falkland Islands and Huab basins of southwestern Gondwana. Palaeogeography, Palaeoclimatology, Palaeoecology, 152, $189-213$

Foster, C. B. 1983. Review of the time frame for the Permian of Queensland. In: Symposium on Permian Geology of Queensland, Proceedings of the Geological Society of Australia Queensland Division, Brisbane 1982, 107-120.

Foster, C.B. \& J. Waterhouse 1988. The Granulatisporites confluens Oppel Zone and Early Permian marine faunas from the Grant Formation on the Barbwire Terrace, Canning Basin, Australia. Australian Journal of Earth Sciences, 35, 135-157.

Foster, C. B. \& Archbold, N. W. 2001. Chronologic anchor points for the Permian and Early Triassic of the eastern Australian basins. In: Weiss, R. E. (ed.) Contributions to geology and paleontology of Gondwana - in honour of Helmut Hopfner, Geological Institute, University of Cologne, 175-199. 
Frakes, L. A., Kemp, E. M. \& Crowell, J. C. 1975. Late Paleozoic glaciation: Part IV, Asia. Geological Society of America Bulletin, 86, 454-464.

Francis, J. E., Woolfe, K. J., Arnot, M. J. \& Barrett, P. J. 1993. In: Permian forests of Allan Hills Antarctica: the palaeoclimate of Gondwanan high latitudes. Special Papers in Palaeontology, 49, 75-83.

Frank, T. D., Jones, A., Fielding, C. \& Thomas, S. 2005. Protracted glacial conditions in eastern Gondwana maintained by strengthened upwelling during marine highstands. Geological Society of America Abstracts with Programs, 37, No. 7, p. 256; 2005 Salt Lake City Annual Meeting (October 16-19, 2005).

Ghosh P. K. \& Mitra N. D. 1972. Sedimentary framework of glacial and periglacial deposits of the Talchir Formation of India. In: Houghton, S. H. (ed.), Proceedings and Papers of the $2^{\text {nd }}$ Gondwana Symposium, South Africa. CSIR, Pretoria, 213-224.

Goldberg, K. 2004. Floral diversity in the assessment of paleoclimate in the Paraná Basin, southern Brasil. Journal of Geology, 112, 719-727.

Gonzalez, C. R. 1997. Upper Palaeozoic glaciation and Carboniferous and Permian faunal changes in Argentina. In: Dickins, J. M. (ed.) Late Palaeozoic and Early Mesozoic circum-Pacific events and their global correlation, Cambridge University Press, 235-243.

Gonzalez-Bonorino, G. 1992. Carboniferous glaciation in Gondwana. Evidence for grounded marine ice and continental glaciation in southwestern Argentina. Palaeogeography, Palaeoclimatology, Palaeoecology, 91, 363-375.

Guit, F. A., Al-Lawati, M. H. \& Nederlof, P. J. R. 1995. Seeking new potential in the 
Early-Late Permian Gharif play, West Central Oman. In: Al-Husseini M. I. (ed.), Geo '94 The Middle East Petroleum Geosciences, 2, Gulf Petrolink, Bahrain, 447-462.

Hart, G. F. 1967. The stratigraphic subdivision and equivalents of the Karroo sequence as suggested by palynology. IUGS Gondwana Symposium Proceedings $\mathbf{1}$, Buenos Aires, 1967, 23-35.

Hudson, R. G. S. \& Sudbury, M. 1959. Permian brachiopoda from south-east Arabia. Notes et mémoires sur le Moyen-Orient, Muséum National d'Histoire Naturelle, Paris, 7, 19-55.

Hughes Clark, M. W. 1988. Stratigraphy and rock unit nomenclature in the oil producing area of interior Oman. Journal of Petroleum Geology, 11, 5-60.

Isbell, J. L. \& Cúneo, N. R. 1996. Depositional framework of Permian coal-bearing strata, southern Victoria Land, Antarctica. Palaeogeography, Palaeoclimatology, Palaeoecology, 125, 217-238.

Isbell, J. L. 1999. The Kukri Erosion Surface; a reassessment of its relationship to rocks of the Beacon Supergroup in the central Transantarctic Mountains, Antarctica. Antarctic Science, 11, 228-238.

Isbell, J. L., Miller, M. F., Wolfe, K. L. \& Lenaker, P. A. 2003. Timing of late Paleozoic glaciation in Gondwana: was glaciation responsible for the development of northern hemisphere cyclothems? Geological Society of America Special Paper, 370, $5-24$

James, N. P., Bone, Y. \& Kyser, T. K. 1997. Brachiopod $\delta^{18} \mathrm{O}$ values do reflect ambient oceanography: Lacepede Shelf, southern Australia. Geology, 25, 551-554. 
Jones, A. T. \& Fielding, C. R. 2004. Sedimentological record of the late Paleozoic glaciation in Queensland, Australia. Geology, 32, 153-156.

Jones, M. J. \& Truswell, E. M. 1992. Late Carboniferous and Early Permian palynostratigraphy of the Joe Joe Group, southern Galilee Basin, Queensland, and implications for Gondwana Stratigraphy. Bureau of Mines and Mineral Resources Journal of Australian Geology and Geophysics, 13, 143-185.

Kelly, S. R. A., Doubleday, P. A., Brunton, C. H. C., Dickins, J. M., Sevastopulo, G. D. \& Taylor, P. D. 2001. First Carboniferous and ?Permian marine macrofaunas from Antarctica and their tectonic implications. Journal of the Geological Society, London, 158, 219-232.

Kemp, E. M. 1975. Palynology of Late Palaeozoic glacial deposits of Gondwanaland. In: Campbell, K.W. (ed.) Gondwana Geology, Australian National University Press, Canberra, 125-134.

Kemp, E. M., Balme, B. E., Helby, R. J., Kyle, R. A., Playford, G. \& Price, P. L. 1977. Carboniferous and Permian palynostratigraphy in Australia and Antarctica: a review. Bureau of Mines and Mineral Resources Journal of Australian Geology and Geophysics, 2, 177-208.

Kneller, B., Milana, J. P., Buckee, C. \& al Ja'aidi, O. 2004. A depositional record of deglaciation in a paleofjord (Late Carboniferous [Pennsylvanian] of San Juan Province, Argentina): the role of catastrophic sedimentation. Geological Society of America Bulletin, 116, 348-367.

Konert, G., Abdulkader, M. A., Al-Hajri, A. A. \& Droste, H. J. 2001. Paleozoic stratigraphy and hydrocarbon habitat of the Arabian Plate. GeoArabia, 6, 407-442. 
Korte, C. Jasper, T., Kozur, H. W. \& Veizer, J. 2005. $\delta^{18} \mathrm{O}$ and $\delta^{13} \mathrm{C}$ of Permian brachiopods: A record of seawater evolution and continental glaciation. Palaeogeography, Palaeoclimatology, Palaeoecology, 224, 333-351.

Korte, C., Kozur, H. W., Joachimski, M. M., Strauss, H., Veizer, J. \& Schwark, L. 2004. Carbon, sulphur, oxygen, and strontium isotope records , organic chemistry and biostratigraphy across the Permian-Triassic boundary in Abadeh, Iran. International Journal of Earth Sciences, 93, 565-581.

Kyle, R. A. 1977. Palynostratigraphy of the Victoria Group of south Victoria Land, Antarctica. New Zealand Journal of Geology and Geophysics, 20, 1081-1102.

Larghi, C. 2005. Dickinsartella fauna from the Saiwan Formation (Oman): a bivalve fauna testifying to the Late Sakmarian (Early Permian) climatic amelioration along the north-eastern Gondwanan fringe. Rivista Italiana di Paleontologia e Stratigrafia, 111, 353-375.

Leonova, T. B. 1998. Permian ammonoids of Russia and Australia. Proceedings of the Royal Society of Victoria, 110, 157-162.

Levell, B. K., Braakman, J. H. \& Rutten, K. W. 1988. Oil-bearing sediments of Gondwana glaciation in Oman. American Association of Petroleum Geologists Bulletin, 72, 775-796.

Lindström, S. 1995. Early Permian palynostratigraphy of the Northern Heimefrontfjella Mountain Range, Dronning Maud Land, Antarctica. Review of Palaeobotany and Palynology, 89, 359-415.

López-Gamundí, O. R. 1997. Glacial-postglacial transition in the late Paleozoic basins 
of southern South America. In: Martini, I. P. (ed.) Late glacial and postglacial environmental changes, OUP, Oxford 147-168.

López-Gamundí, O. R., Limarino, C. O. \& Césari, S. 1992. Late Paleozoic paleoclimatology of central western Argentina. Palaeogeography, Palaeoclimatology, Palaeoecology, 91, 305-329.

Lowenstam H. A. 1961. Mineralogy, ${ }^{18} \mathrm{O} /{ }^{16} \mathrm{O}$ ratios and strontium and magnesium contents of recent and fossil brachiopods and their bearing on the history of the oceans. Journal of Geology, 69, 241-260.

Lowenstam H. A. 1964. Palaeotemperatures of the Permian and Cretaceous Periods. In: A. E. M. Nairn (ed.) Problems in Palaeoclimatology, Interscience, London, 227248.

MacRae, C. S. 1988. Palynostratigraphical correlation between the Lower Karoo sequence of the Waterburg and Pafuri coal basins and the Hammanskraal plant macrofossil locality, RSA. Memoirs of the Geological Survey of South Africa, 75, 1217.

Marques-Toigo, M. 1991. Palynobiostratigraphy of the southern Brasilian Neopalaeozoic Gondwana sequence. Proceedings of the Seventh International Gondwana Symposium, Instituto de Geosciencias, University of Sao Paulo, 503-516.

Martini, I. P. \& Banks, M. R. 1989. Sedimentology of the cold-climate, coal bearing, Lower Permian, Lower Freshwater Sequence of Tasmania. Sedimentary Geology, 64, $25-41$.

Martini, I. P. \& Glooschenko, W. A. 1985. Cold climate peat formation in Canada and 
its relevance to Lower Permian Coal Measures of Australia. Earth Science Reviews, 22, 107-140.

Millsteed, B. D. 1999. Palynology of the Early Permian coal-bearing deposits near Vereeniging, Free State, South Africa. Bulletin of the Council for Geoscience, 124, 177.

Nyambe, I. A. \& Utting, J. 1997. Stratigraphy and palynostratigraphy, Karoo Supergroup (Permian and Triassic), mid-Zambezi Valley, southern Zambia. Journal of African Earth Sciences, 24, 563-583.

Oesterlen, P. \& Millsteed, B. 1994. Lithostratigraphy palaeontology and sedimentary environments of the western Cabora Bassa Basin, lower Zambezi Valley, Zimbabwe. South African Journal of Geology, 97, 205-224.

Osterloff, P. L., Al-Harthy, A., Penney, R., Spaak, P., Al-Zadjali, F., Jones, N. S., Knox, R. W. O’B., Stephenson, M. H., Oliver, G. \& Al-Husseini, M. I. 2004. Gharif and Khuff formations, subsurface Interior Oman. In: Al-Husseini, M (ed.)

Carboniferous, Permian and Early Triassic Arabian stratigraphy, GeoArabia Special Publication 3, Gulf PetroLink, Manama, Bahrain, 83-147.

Pant, D. D. 1996. The biogeography of the late Paleozoic floras of India. Review of Palaeobotany and Palynology, 90, 79-98.

Potter, P. E., Franca, A. B., Spencer, C. W. \& Caputo, M. V. 1995. Petroleum in glacially-related sandstones of Gondwana: a review. Journal of Petroleum Geology, 18, 397-420.

Powis, G. D. 1979. Palynology of the Late Palaeozoic glacial sequence, Canning 
Basin, Western Australia. Unpublished Ph.D. thesis, University of Western Australia.

Powis, G. D. 1984. Palynostratigraphy of the Late Carboniferous sequence, Canning Basin, W. A. In: Purcell, P. G. (ed.) The Canning Basin, W. A: Proceedings of the Geological Society of Australia/Petroleum Geological Society of Australia Symposium. Perth, 1984, 429-438

Price, P. L. 1983. A Permian palynostratigraphy for Queensland. In: Foster, C. B. (ed.) Permian Geology of Queensland, Geological Society of Australia, Brisbane, $155-211$.

Price, P. L. 1997. Permian to Jurassic palynostratigraphic nomenclature of the Bowen and Surat basins. In: P. Green (ed.) The Surat and Bowen Basins, southeast Queensland, Queensland Department of Mines and Energy, Brisbane, 137-178. Russo, A., Archangelsky, S. \& Gamerro, J. C. 1980. Los depósitas supra Palaeozoicos en el subsuelo de la Llanura Chaco-Pampeana, Argentina. Actas del II Congreso Argentino de Paleontología y Bioestratigrafía y I Congreso Latinoamericano de Paleontología 1978, 4, 157-173.

Santos, P. R. dos, Rocha-Campos, A. C. \& Canuto, J. R. 1996. Patterns of late Palaeozoic deglaciation in the Paraná Basin, Brazil. Palaeogeography, Palaeoclimatology, Palaeoecology, 125, 165-184.

Sastry M. V. A. \& Shah S. C. 1964. Permian marine transgression in peninsular India. $22^{\text {nd }}$ International Geological Congress Proceedings, 3, 139-150.

Scheffler, K., Hoernes, S. \& Schwark, L. 2003. Global changes during CarboniferousPermian glaciation of Gondwana: linking polar and equatorial climate evolution by 
chemical proxies. Geology, 31, 605-608.

Shah, S. C. \& Sastry, M. V. A. 1975. Significance of Early Permian marine faunas of Peninsular India. In: Campbell, K.W. (ed.) Gondwana Geology. Australian National University Press, Canberra, 391-395.

Sharland, P. R., Archer, R., Casey, D. M., Davies, R. B., Hall, S. H., Heward, A. P.

Horbury, A. D. \& Simmons, M. D. 2001. Arabian Plate Sequence Stratigraphy, GeoArabia Special Publication 2, Gulf Petrolink, Bahrain, 371pp.

Simanauskas T. \& Cisterna G. A. 2001. Braquiopodos articulados de la formacion El Paso, Paleozoico superior, Precordillera Argentina. Revista Española de Paleontología, 16, 209-222.

Stephenson, M. H. 1998. Stratigraphic and systematic palynology of Permian and Permo-Carboniferous rocks of Oman and Saudi Arabia. Unpublished PhD thesis, University of Sheffield.

Stephenson, M. H. \& Osterloff, P. L. 2002. Palynology of the deglaciation sequence represented by the Lower Permian Rahab and Lower Gharif members, Oman. American Association of Stratigraphic Palynologists Contribution Series, 40, 1-32.

Stephenson, M. H., Osterloff, P. L. \& Filatoff, J. 2003. Integrated palynological biozonation of the Permian of Saudi Arabia and Oman: progress and problems. GeoArabia, 8, 467-496.

Stephenson, M. H., Leng, M. J., Vane, C. H., Osterloff, P. L. \& Arrowsmith C. 2005. Investigating the record of Permian climate change from argillaceous sediments, Oman. Journal of the Geological Society, London, 162, 1-11. 
Stollhofen, H., Stanistreet, I. G., Bangert, B. \& Grill, H. 2000. Tuffs, tectonism and glacially related sea-level changes, Carboniferous-Permian, southern Namibia. Palaeogeography, Palaeoclimatology, Palaeoecology, 161, 127-150.

Tabor, N. J. \& Montañez, I. P. 2002. Shifts in late Paleozoic atmospheric circulation over western equatorial Pangea: insights from pedogenic mineral $\delta^{18} \mathrm{O}$ compositions. Geology, 30, 1127-1130.

Tabor, N. J. \& Montañez, I. P. 2005. Oxygen and hydrogen isotope compositions of Permian pedogenic phyllosilicates: Development of modern surface domain arrays and implications for palaeotemperature reconstruction. Palaeogeography, Palaeoclimatology, Palaeoecology, 223, 127-146.

Taylor, T. N., Taylor, E. L. \& Cúneo, N. 1992. The present is not the key to the past: a polar forest from the Permian of Antarctica. Science, 257, 1675-1677.

Theron, J. N. \& Blignault, H. J. 1975. A model for the sedimentation of the Dwyka glacials in the southwestern Cape. In: Campbell, K.W. (ed.) Gondwana Geology, Australian National University Press, Canberra, 347-356.

Tiwari, R. S. 1994. Palynoevent stratigraphy in Gondwana sequence of India. Ninth International Gondwana Symposium, Hyderabad, India, January 1994, 3-19.

Truswell, E. M. 1980. Permo-Carboniferous palynology of Gondwanaland: progress and problems in the decade of 1980. Bureau of Mines and Mineral Resources Journal of Australian Geology and Geophysics, 5, 95-111.

Veevers, J. J. \& Powell, C. McA. 1987. Late Paleozoic glacial episodes in 
Gondwanaland reflected in transgressive-regressive depositional sequences in Euramerica. Geological Society of America Bulletin, 98, 475-487.

Veevers, J. J. \& Tewari, R. C. 1995. Gondwana master basin of Peninsular India between Tethys and the interior of the Gondwanaland Province of Pangea: Boulder, Colorado, Geological Society of America Memoir, 187, 72pp.

Veevers, J. J., Powell, C. M., Collinson, J. W., and López-Gamundí, O. R. 1994.

Synthesis. In: Veevers, J. J., Powell, C. M. (eds) Permian-Triassic Pangean basins and foldbelts along the Panthalassan Margin of Gondwanaland. Boulder, Colorado, Geological Society of America Memoir, 184, 331-353.

Veizer, J., Bruckschen, P., Pawellek, F., Diener, A., Podlaha, O. G., Carden, G. A. F., Jasper, T., Korte, C., Strauss, H., Azmy, K. \& Ala, D. 1997. Oxygen isotope evolution of Phanerozoic seawater. Palaeogeography, Palaeoclimatology, Palaeoecology, 132, $159-172$.

Veizer, J., Ala, D., Azmy, K., Bruckschen, P., Buhl, D., Bruhn, F., Carden, G. A. F., Diener, A., Ebneth, S., Godderis, Y., Jasper, T., Korte, C., Pawellek, F., Podlaha, O.

G. \& Strauss, H. 1999. ${ }^{87} \mathrm{Sr} /{ }^{86} \mathrm{Sr}, \delta^{13} \mathrm{C}$ and $\delta^{18} \mathrm{O}$ evolution of Phanerozoic seawater. Chemical Geology, 161, 59-88.

Venkatachala, B. S. \& Tiwari, R. S. 1987. Lower Gondwana marine incursions: periods and pathways. Palaeobotanist, 36, 24-29.

Venkatachala, B. S., Tiwari, R. S. \& Vijaya 1995. Diversification of spore-pollen character states in the Indian Permian. Review of Palaeobotany and Palynology, 85, 319-340. 
Vergel, M. 1993. Palinoestratigrafía de la secuencia Neopalaeozoica de la Cuenca Chacoparanense, Argentina. 12th International Congress of the Stratigraphy and Geology of the Carboniferous and Permian, Buenos Aires 1993, 1, 201-212.

Vijaya, 1994. Advent of Gondwanan deposition on Indian Peninsula: a palynological reflection and relationship. Ninth International Gondwana Symposium, Hyderabad, India, 283-298.

Vijaya, Tripathi, A. \& Ram Awatar, 2001. Vertical distribution of spore and pollen index species in the Permian sequence on Peninsular India. In: Weiss, R. E. (ed.) Contributions to geology and paleontology of Gondwana - in honour of Helmut Hopfner, Geological Institute, University of Cologne, 475-495.

Visser, J. N. J. \& Young, G. M. 1990. Major element geochemistry and paleoclimatology of the Permo-Carboniferous glacigene Dwyka Formation and postglacial mudrocks in southern Africa. Palaeogeography, Palaeoclimatology, Palaeoecology, 81, 49-57.

Visser, J. N. J. 1995. Post-glacial Permian stratigraphy and geography of southern and central Africa: boundary conditions for climatic modelling. Palaeogeography, Palaeoclimatology, Palaeoecology, 118, 213-243.

Visser, J. N. J. 1996. Controls on Early Permian shelf deglaciation in the Karoo Basin of South Africa. Palaeogeography, Palaeoclimatology, Palaeoecology, 125, 129-139.

Visser, J. N. J. 1997. Deglaciation sequences in the Permo-Carboniferous Karoo and Kalahari basins of southern Africa: a tool in the analysis of cyclic glaciomarine basin fills. Sedimentology, 44, 507-521. 
Waterhouse, J. B. 1997. The Permian Time-scale. Permophiles, 30, 6-8.

Wilson, L. R. 1963. Teratological forms in pollen of Pinus flexilis James. Journal of Palynology, 1, 106-110.

Wopfner, H. 1999. The Early Permian deglaciation event between East Afica and northwestern Australia. Journal of African Earth Sciences, 29, 77-90.

Wopfner, H. \& Kreuser, T. 1986. Evidence for Late Palaeozoic glaciation in southern Tanzania. Palaeogeography, Palaeoclimatology, Palaeoecology, 56, 259-275.

Wopfner, H. \& Diekmann, B. 1996. The Late Palaeozoic Idusi Formation of southwest Tanzania: a record of change from glacial to postglacial conditions. Journal of African Earth Sciences, 22, 575-595.

Wopfner, H. \& Casshyap, S. M. 1997. Transition from freezing to subtropical climates in the Permo-Carboniferous of Afro-Arabia and India. In: Martini, I. P. (ed.) Late glacial and postglacial environmental changes, OUP, Oxford, 192-212.

Ziegler, A. M., Rees, P. McA. \& Naugolnykh, S. V. 2002. The Early Permian floras of Prince Edward Island, Canada: differentiating global from local effects of climate change. Canadian Journal of Earth Sciences, 39, 223-238.

\section{Figure Captions}

Fig. 1. Chief basins in the Early Permian of Gondwana.

Fig. 2. Correlation of Thuleilat (TL) well sections of Oman based on palynology, and flattened on the base of the U. omanensis Biozone. Note that the boundaries between 
the Rahab member, the Al Khlata Formation and the Gharif Formation are not defined precisely in the Thuleilat wells. ? Rm = possible position of Rahab member.

Reproduced with permission from Stephenson et al. (2005). Inset map shows location.

Fig. 3. Gross quantitative palynological character, ranges of selected palynomorphs, palynofacies, and $\delta^{13} \mathrm{C}_{\text {org }}$ values for the Thuleilat-42 well section. $\mathrm{AOM}=$ amorphous organic matter. Reproduced with permission from Stephenson et al. (2005).

Fig. 4. Distribution of Asselian-Sakmarian palynological and macrofaunal assemblages in selected basins across Gondwana. Note that only sections with established faunal successions are included, thus Africa and Antarctica are excluded. As discussed in the text it is not possible to correlate precisely in this time interval, thus this diagram is not primarily aimed at correlation but at comparing biotic responses to deglaciation. Argentina, Rio Blanco Basin assemblages after Cisterna \& Simanauskas (2000); no palynological data specific to Rio Blanco Basin. Oman Basin biozones after Angiolini et al. (2003), Stephenson \& Osterloff (2002) and Stephenson et al. (2003). Indian basins biozones after Vijaya et al. (2001). Western Australian biozones after Archbold (2001, Carnarvon Basin) and Backhouse (1991, Collie Basin). Eastern Australian biozones after Archbold (2001) and Price (1997).

Fig. 5. Running $\delta^{13} \mathrm{C}$ mean (a) and $\delta^{18} \mathrm{O}$ mean (b) (2 Ma step, 5 Ma window), based on well preserved brachiopod shells for the interval 296-253 Ma. The Early Permian brachiopod data are entirely derived from the Southern Urals, which were in a palaeoequatorial position, although it is assumed that the brachiopods were living in basins which were open to the Tethys Ocean. Reproduced with permission from Korte et al. (2005). 


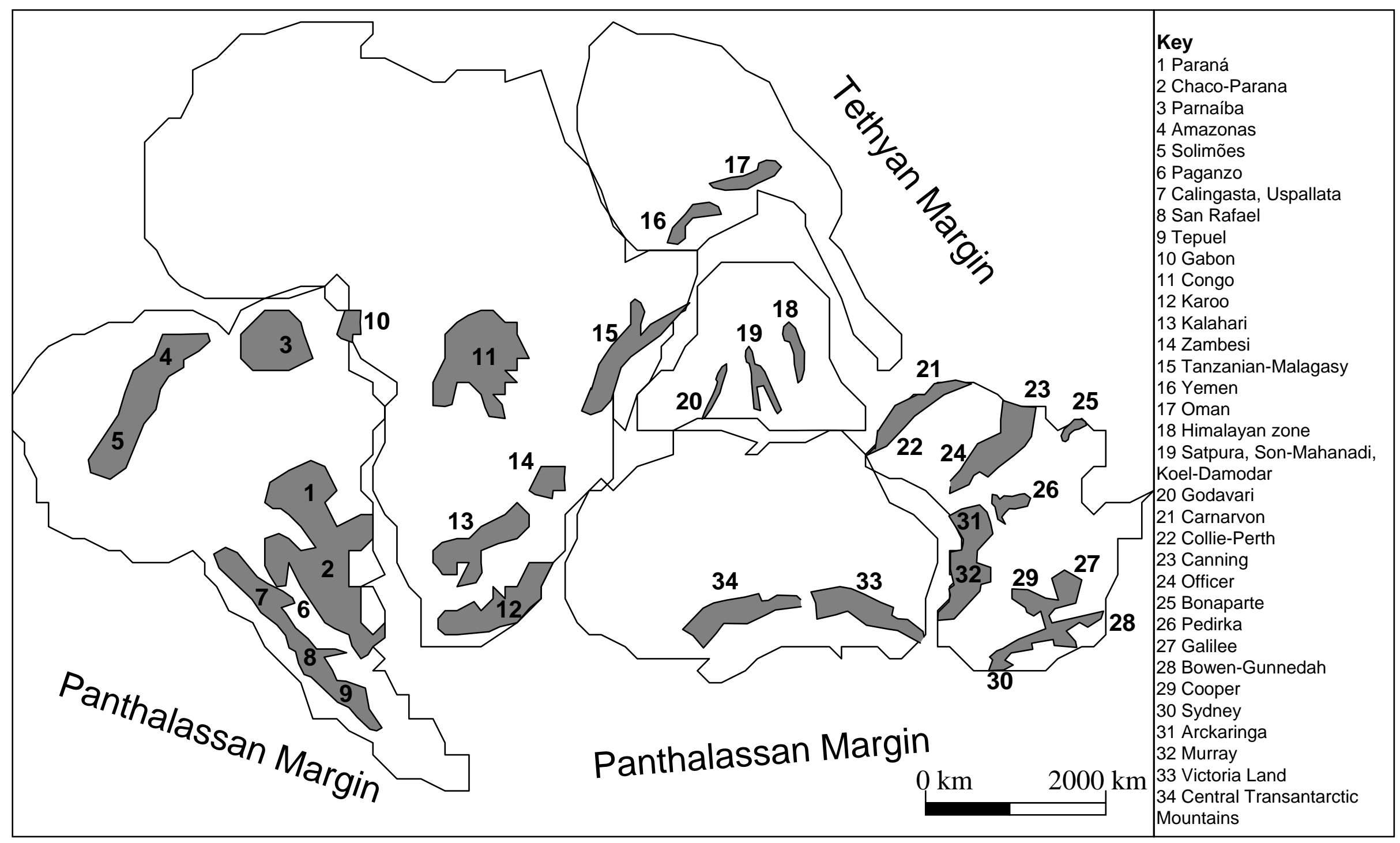




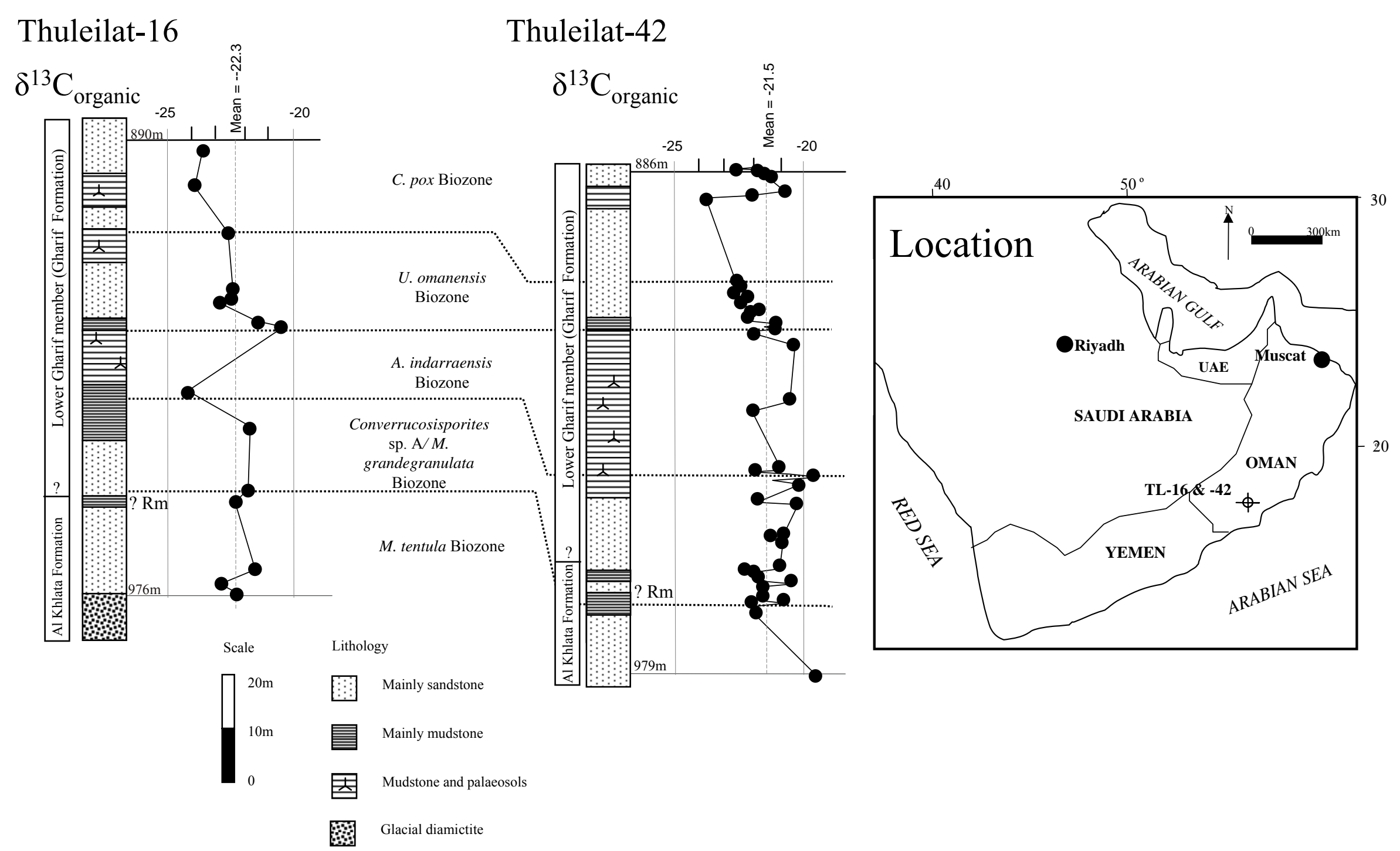




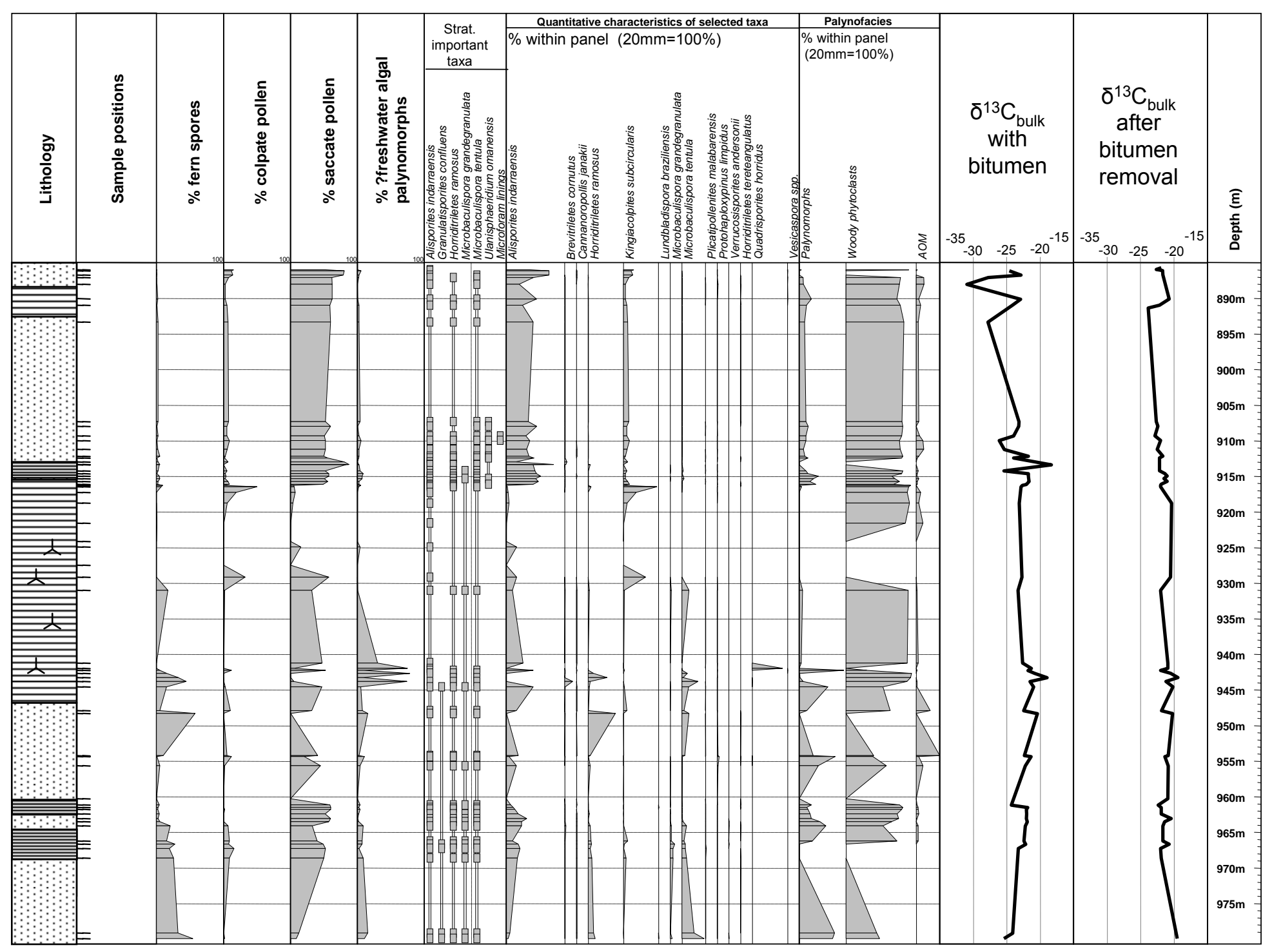




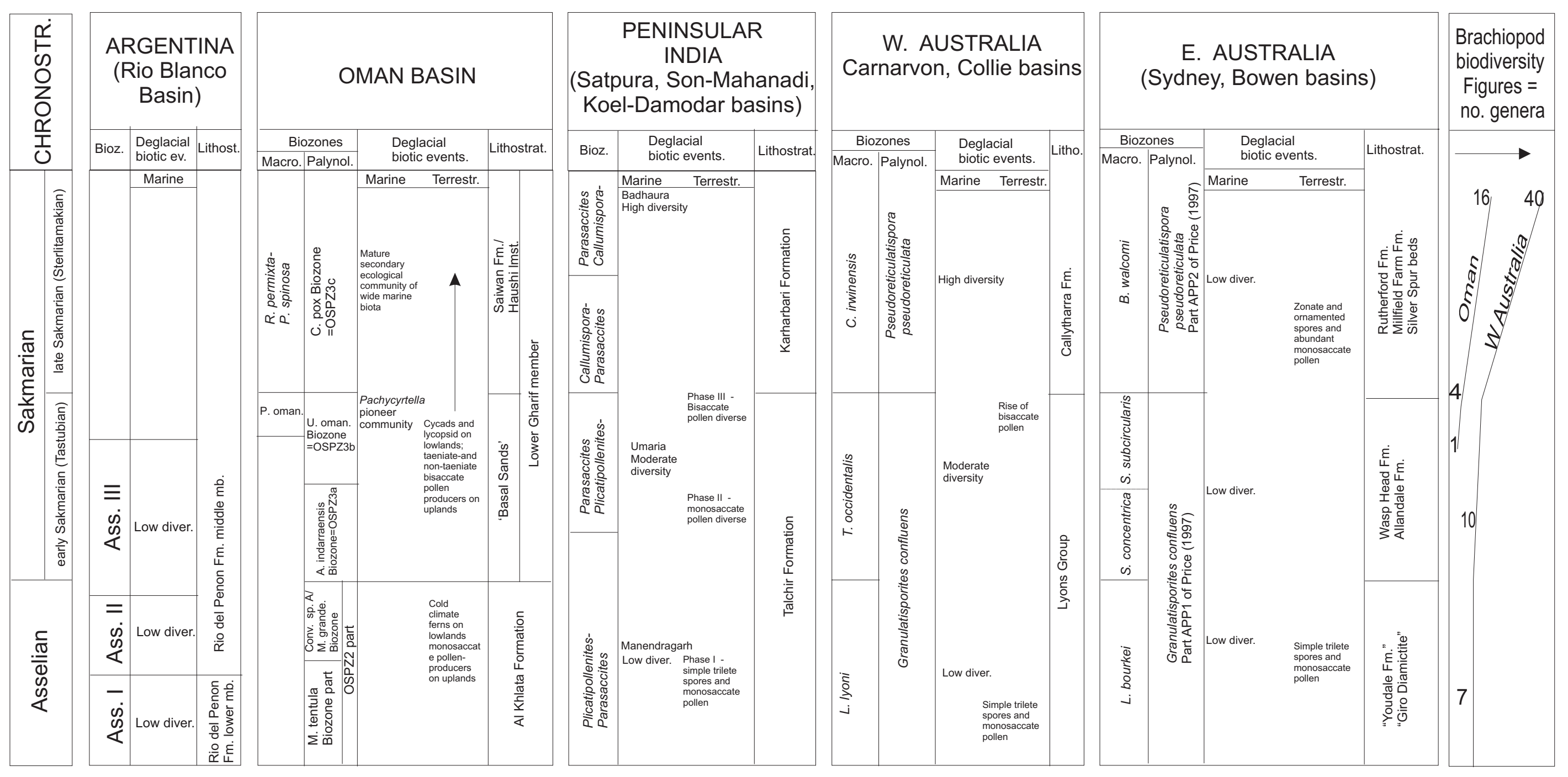




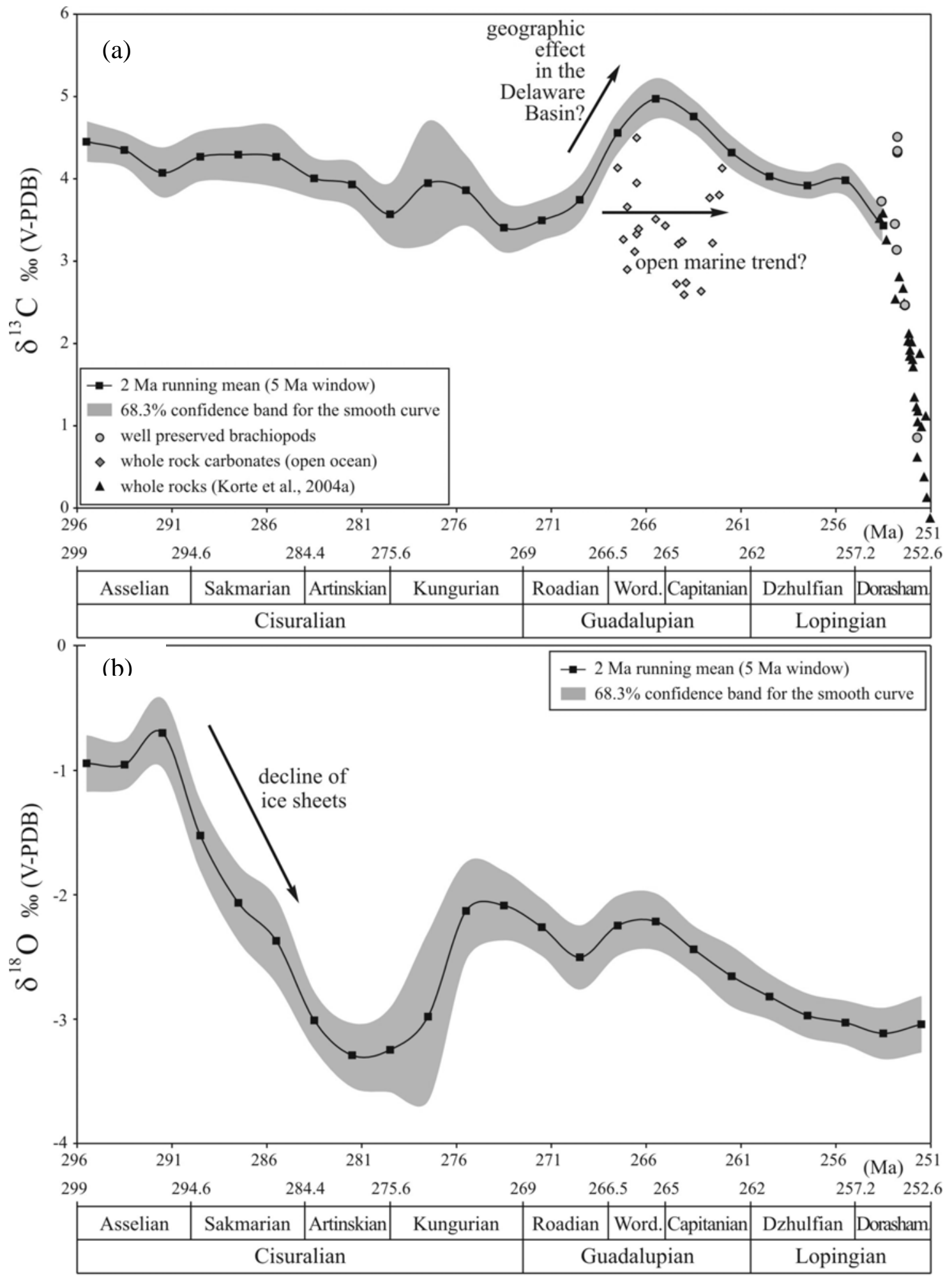

Fig 5 